University of South Florida

DIGITAL COMMONS

Digital Commons @ University of

@ UNIVERSITY OF SOUTH FLORIDA

South Florida

The Inside, Outside, and Upside Downs of

Children's Literature: From Poets and Pop-ups

to Princesses and Porridge

Teaching and Learning

$1-1-2016$

\title{
Chapter 10: Waxing Poetic with Deliberate Description and Aesthetic Argument
}

Jenifer Jasinski Schneider

University of South Florida, jschneid@usf.edu

Follow this and additional works at: https://digitalcommons.usf.edu/childrens_lit_textbook

Part of the Education Commons

\section{Recommended Citation}

Schneider, Jenifer Jasinski, (2016). Waxing Poetic with Deliberate Description and Aesthetic Argument. In The Inside, Outside, and Upside Downs of Children's Literature: From Poets and Pop-ups to Princesses and Porridge (p. 267-300). http://dx.doi.org/10.5038/9780977674411.ch10

This Book Chapter is brought to you for free and open access by the Teaching and Learning at Digital Commons @ University of South Florida. It has been accepted for inclusion in The Inside, Outside, and Upside Downs of Children's Literature: From Poets and Pop-ups to Princesses and Porridge by an authorized administrator of Digital Commons@ @niversity of South Florida. For more information, please contact digitalcommons@usf.edu. 


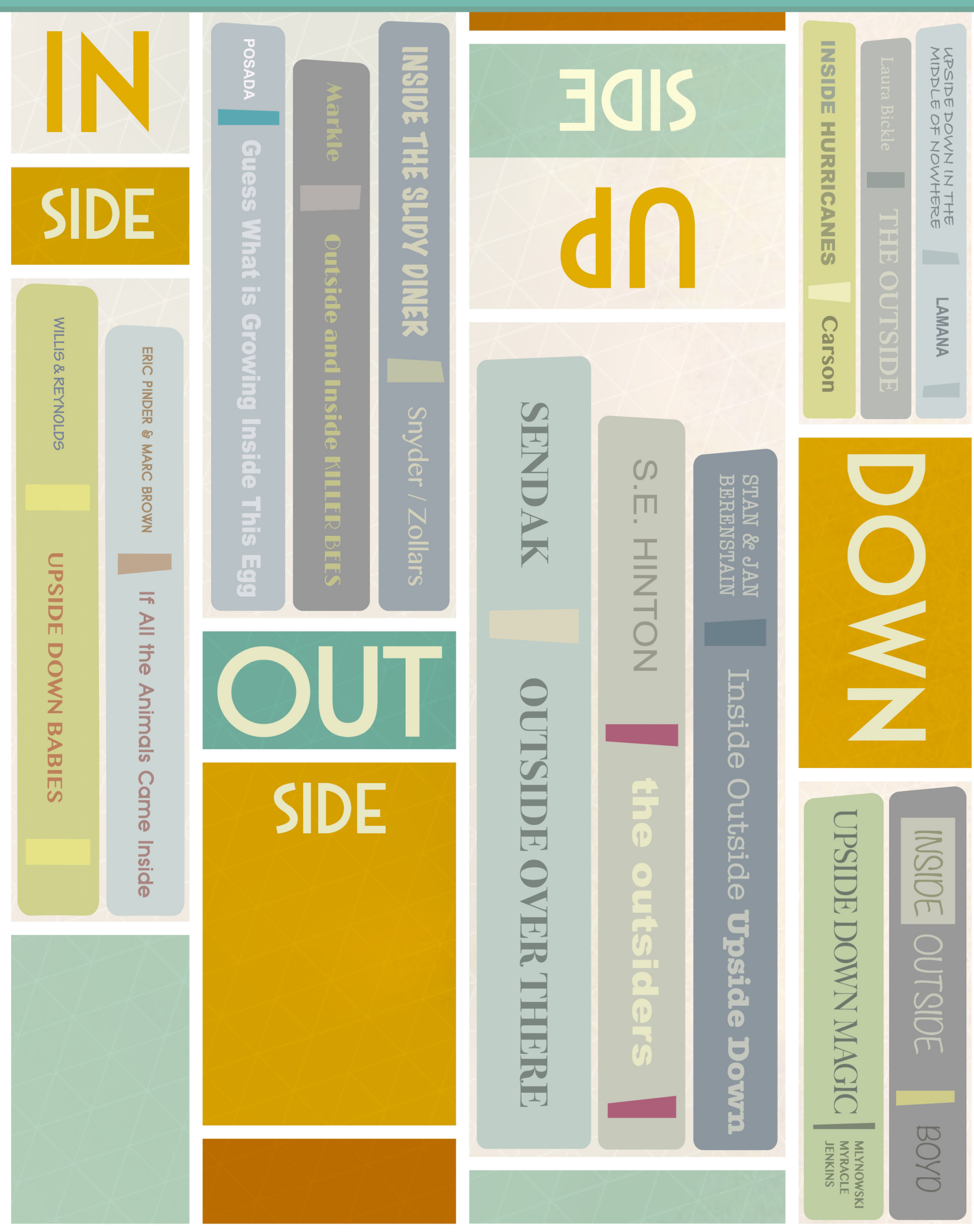

\section{THE INSIDE, OUTSIDE, AND UPSIDE DOWIS From Poets and Pop-ups to OF CHILDREN'S LITERATURE Princesses and Porridge}




\section{The Inside, Outside, and Upside Downs of Children's Literature: From Poets and Pop-ups to Princesses and Porridge}

Jenifer Jasinski Schneider, Ph.D. 
Copyright

Published by The University of South Florida Library, 4202 E. Fowler Avenue, Tampa, FL 33620.

Copyright (C2016 by Jenifer Jasinski Schneider. All rights reserved.

\section{(c) $(1) \odot$}

This work is licensed under a Creative Commons Attribution-NonCommercial-NoDerivatives 4.0 International License.

Author and Editor in Chief: Jenifer Jasinski Schneider

Editorial Director: Monica Metz-Wiseman

Media Project Manager and Producer: Christine Brown

Video Producers and Editors: Jared Brown, Jason Su, Ian Crenshaw, Jessica Brennen,

Diana Trueman, Jeremy Willis

Art Director: Stephanie Rivera

Illustrators and Multimedia Designers: William Tillis and Elise Michal

Copyright Coordinator: LeEtta M. Schmidt

Open-Access Editor: Jason Boczar

Editorial Manager: Carol Ann Borchert

Editorial Project Manager: Chelsea Johnston

Cover image book credits:

Upside Down Babies by Jeanne Willis and Adrian Reynolds (C)2013 Andersen Press; If All the Animals

Came Inside by Eric Pinder and Marc Tolon Brown (C)2012 Little, Brown and Company; Guess What Is Growing Inside This Egg by Mia Posada (C2007 Millbrook Press; Outside and Inside Killer Bees by Sandra Markle (C)2004 Walker \& Co.; Inside the Slidy Diner by Laurel Snyder and Jaime Zollars (C)2008 Tricycle Press; Outside Over There by Maurice Sendak (C)1989 HarperCollins; The Outsiders by S.E. Hinton, original cover art by Robert Hunt (C1967 Viking Press. Mass Market edition (C1997 Speak; Inside Outside Upside Down by Stan and Jan Berenstain (C1968 Random House; Upside Down Magic by Sarah Mlynowski, Lauren Myracle, and Emily Jenkins (C)2015 Scholastic Press; Inside Outside by Lizi Boyd (C)2013 Chronicle Books; Inside Hurricanes by Mary Kay Carson (C)2010 Sterling; The Outside by Lauren Bickle (C)2013 Houghton Mifflin Harcourt; Upside Down in the Middle of Nowhere by Julie T.

Lamana (C)2014 Chronicle Books.

Library of Congress Cataloging-in-Publication Data

Schneider, Jenifer Jasinski, 1968-

The Inside, Outside, and Upside Downs of Children's Literature: From Poets and Pop-ups to Princesses and Porridge / Jenifer Jasinski Schneider.

ISBN- 978-0-9776744-1-1 eBook

ISBN- 978-0-9776744-2-8 print

The Internet addresses listed in the text were accurate at the time of publication. 


\section{TEXTUAL TENDENCEES AND OPEN AND CLOSE READINGS}

\section{SECTION 3}




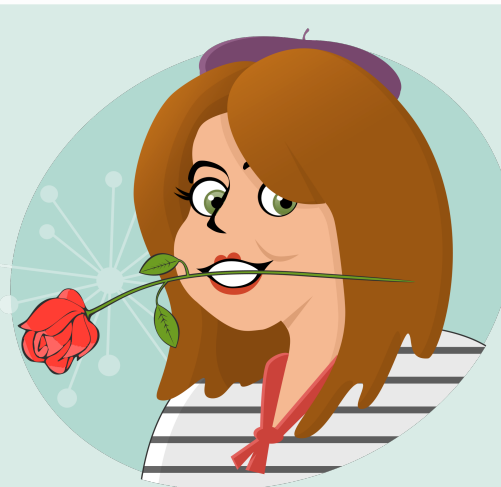

\section{Poetry}

What is poetry? Who knows?

Not the rose, but the scent of the rose;

Not the sky, but the light in the sky;

Not the fly; but the gleam of the fly;

Not the sea; but the sound of the sea;

Not myself, but what makes me

See, hear, and feel something that prose

Cannot; and what it is who knows?

(Eleanor Farjeon, 1938) 
In her poem, Poetry, Eleanor Farjeon used imagery, sensory details, repetition, and a series of metaphors to communicate her message. Her purpose was to define poetry, and in doing so, she engaged in a succinct form of writing to describe an elusive genre. Farjeon was not the first person to attempt such a definition.

Aristotle also tried to capture the essence of poetry. In Poetics (c. 335 BCE) Aristotle formed categories and organized various kinds of poetry into systems, identifying the "essential quality" of each (Telford, 1961, p. 1). His list of poetic forms included "Epic poetry and Tragedy, Comedy also and Dithyrambic poetry."

As children, teenagers, and college students, many of us have experienced poetry as an approximation of Aristotle's method: we categorized the types of poetry, conducted close analyses of the language in poetry, and discovered the aesthetic representations within the words (Figure 10.1). We memorized poems and we also read the great poets: Wordsworth, Yeats, Frost (Figure 10.2), Whitman, Poe, Keats, Shakespeare, Eliot, Thoreau.
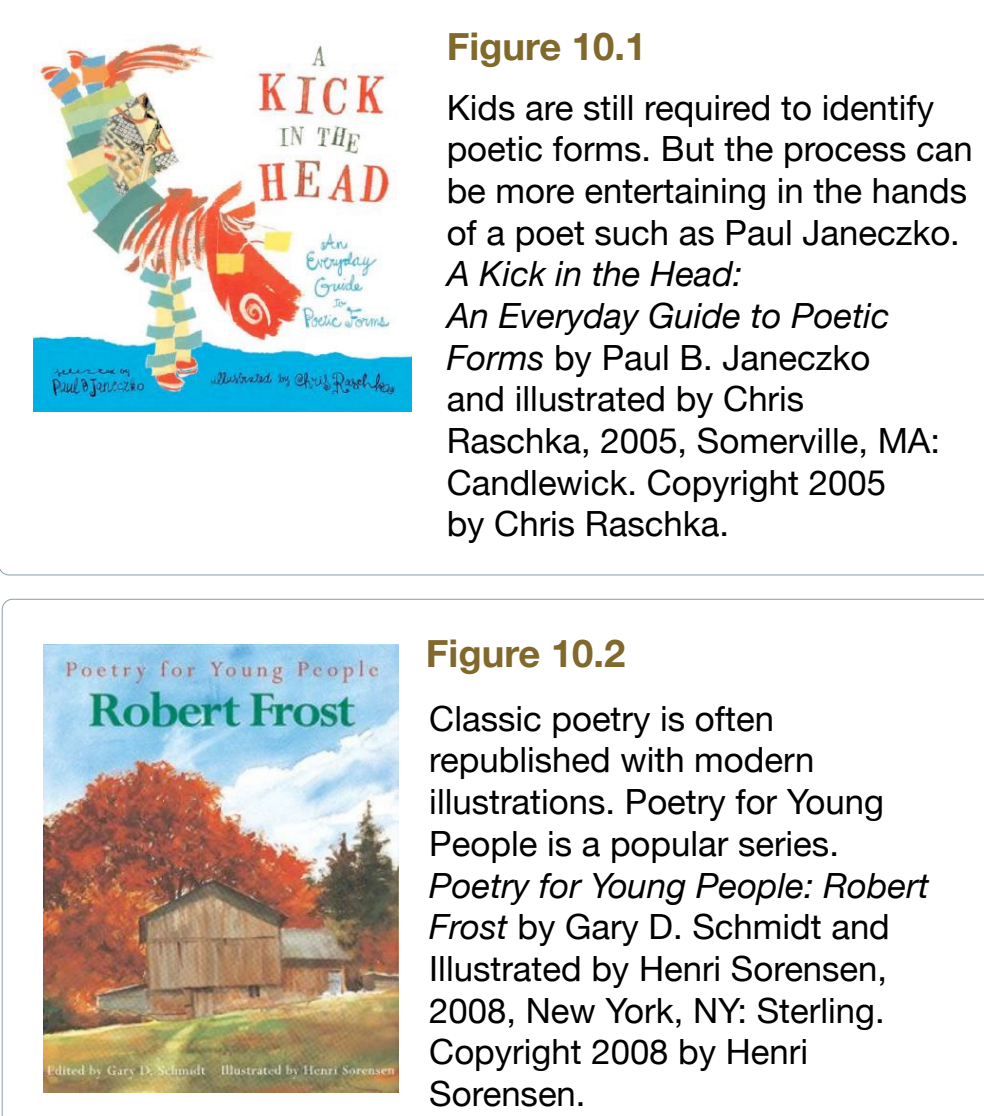

\section{Figure 10.2}

Classic poetry is often republished with modern illustrations. Poetry for Young People is a popular series. Poetry for Young People: Robert Frost by Gary D. Schmidt and Illustrated by Henri Sorensen, 2008, New York, NY: Sterling. Copyright 2008 by Henri Sorensen.

In $5^{\text {th }}$ grade, Sr. Margaret required my class to memorize and recite "The Charge of the Light Brigade" by Alfred Lloyd Tennyson. The poem is about the Battle of Balaclava during the Crimean War. Here is the first stanza.

Half a league half a league, Half a league onward, All in the valley of Death Rode the six hundred:

'Forward, the Light Brigade! Charge for the guns' he said: Into the valley of Death Rode the six hundred. - See more at: http://www.nationalcenter.org/ChargeoftheLightBrigade.html\#sthash.YvI72enH.dpuf

I still remember the experience and I can recite some of the poem. Do you think that's a good thing?

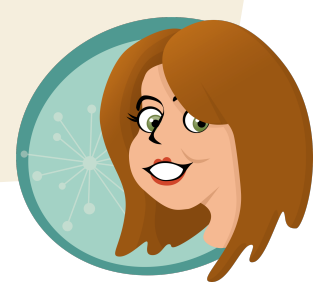


Here is one example.

\section{To A Young Girl}

My dear, my dear, I know

More than another

What makes your heart beat so;

Not even your own mother

Can know it as I know,

Who broke my heart for her

When the wild thought,

That she denies

And has forgot,

Set all her blood astir

And glittered in her eyes.

(William Butler Yeats, 1919) 
If we were extra lucky, our teachers also introduced us to poetry by great women: Dickenson (Figure 10.3), Barrett Browning, Plath, Brontë.

These great poets were excellent wordsmiths. They crafted lyrical phrases about people, places, events, and feelings in ways that were uncommon. Their abilities to use precise, descriptive language gave readers new insight and an opportunity to re-see the world (Figure 10.4).

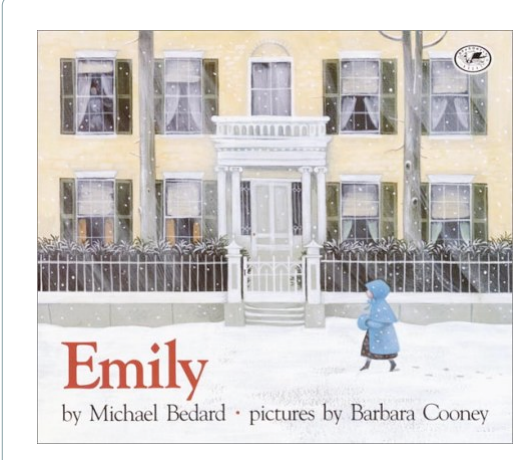

Figure 10.3

Emily Dickenson is one of the most important poets, male or female. Details about her work and life are told by storytellers and illustrators. Emily by Michael Bedard and illustrated by Barbara Cooney, 2002, New York, NY: Dragonfly. Cover art copyright 2002 by Barbara Cooney.

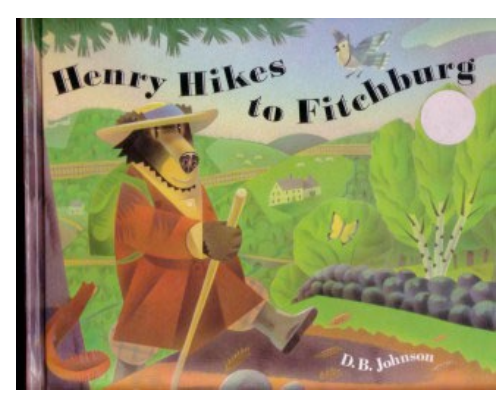

\section{Figure 10.4}

Although this isn't a book of poetry, the Henry Hikes series is inspired by the writing of Henry David Thoreau. Henry Hikes to Fitchburg by D.B. Johnson, 2006, New York, NY: HMH Books for Young Readers. Copyright 2006 by D.B. Johnson.

To evaluate descriptive books based primarily on the text, I use a combination of criteria from the NCTE Award for Excellence in Poetry for Children (ALA), the John Burroughs Riverby Award (American Museum of Natural History), and the Newbery Medal and Printz Award (ALA). Depending on the book, one or more of these criteria will apply:

- Perceptive and artistic accounts of direct experiences in the world

- Demonstrate authenticity of voice

- Use language and form in fresh ways

- Excellent, engaging, and distinctive use of clear and concise language.

- Excellent, engaging and distinctive use of vivid language.

- Excellent, engaging and distinctive use of sensory language.

- Appropriate structure to highlight the topic

- Appropriate organization with clear sequencing and logical development

If the description is presented in the form of a picturebook, I use the following criteria from the Caldecott Medal (ALA) as well.

- Excellence of execution in the artistic technique employed;

- Excellence of pictorial interpretation of theme or topic;

- Appropriateness of style of illustration to the theme or topic;

- Delineation of information through the pictures;

- Excellence of presentation in recognition of the intended audience. 


\section{How Do I Love Thee?}

How do I love thee? Let me count the ways.

I love thee to the depth and breadth and height

My soul can reach, when feeling out of sight

For the ends of Being and ideal Grace.

I love thee to the level of every day's

Most quiet need, by sun and candlelight.

I love thee freely, as men strive for Right;

I love thee purely, as they turn from Praise.

I love with a passion put to use

In my old griefs, and with my childhood's faith.

I love thee with a love I seemed to lose

With my lost saints, I love thee with the breath,

Smiles, tears, of all my life! and, if God choose,

I shall but love thee better after death.

(Elizabeth Barrett Browning, 1850) 
The women's perspectives certainly added new twists to the content of poetry. In addition to writing about love and sexuality, female poets also wrote about injustice, death, and darker motifs (Figure 10.5). They tackled history and social issues alongside explorations of human existence. But their language and ways with words were not necessarily relatable to us-the youth who were required to read them.

Therefore, those of us who were super lucky may have been introduced to more accessible, but simultaneously more challenging, poets from different cultural, racial, and ethnic backgrounds: Hughes (Figure 10.6), Angelou, Wheatley, Brooks, McKay, Clifton, Cisneros, Soto, Neruda, Marti, Mora, Harjo.

By reading poetry from diverse poets, we could see how difficult topics were tackled differently. Poetic language changed. The sensibilities and diction of Victorian England or 19th Century New England gave way to urban, immigrant, disenfranchised, powerful, and hopeful voices who intended to describe and persuade.

For example, in Harriet, Lucille Clifton challenges poetic and descriptive traditions with her content (celebrating strong Black women at the height of the Civil Rights movement), her language (using Black English vernacular to create the sounds of speech), and conventions (using lower case letters throughout to create the informal feeling of a private note or journal entry).

Modern poets may be more relatable to modern audiences (Figure 10.7), but not necessarily to young audiences. I'm certainly not one to prohibit youth from reading adult poetry; however, there is something missing from adult poetry that children need-the experiences and perspectives of youth.

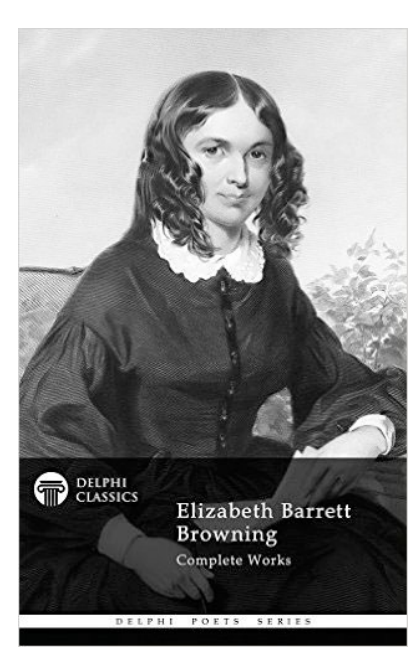

Figure 10.5

Dark, dreary, and dead. These are the poets of my youth. Complete Works of Elizabeth Barrett Browning (Delphi Poets Series), 2013, Delphi Classics, Amazon Digital Services.

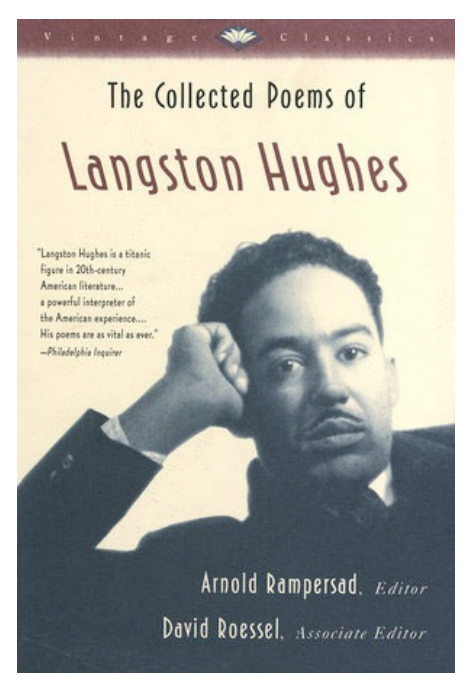

Figure 10.6

Langston Hughes was one of many influential poets of the Harlem Renaissance. The Collected Poems of Langston Hughes, edited by Arnold Rampersad, 1995, New York, NY: Vintage. Copyright 1995 by Arnold Rampersad and Langston Hughes.

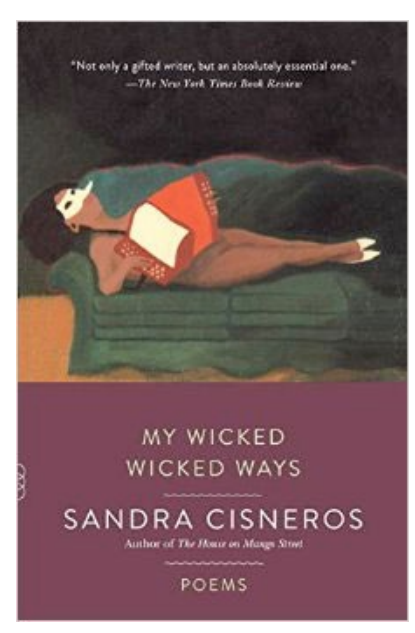

Figure 10.7

Sandra Cisneros' poetry reflected her human experience. My Wicked Wicked Ways by Sandra Cisneros, 1987, Berkeley, CA: Third Women Press. Cover for 3rd edition copyright by Vintage. 
Those of you who are lottery lucky know what I mean. You have read poetry written specifically for children and adolescents:

Silverstein, Prelutsky, Greenfield, Ciardi, Grimes, Adoff, Fisher, McCord, Merriam, Kuskin, Worth, Kennedy, Florian (Figure 10.8).

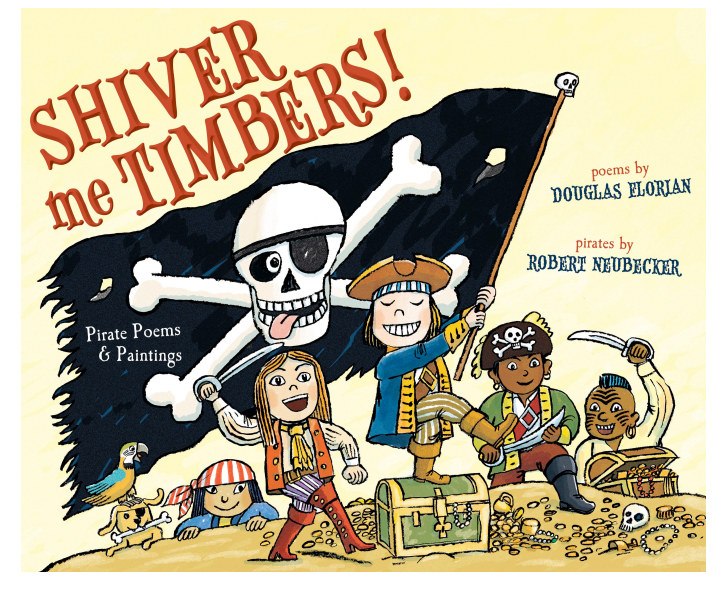

Figure 10.8

Poets, such as Douglas Florian, create topical and thematic books of poetry for children. Shiver Me Timbers! Pirate Poems and Paintings by Douglas Florian and illustrated by Robert Neubecker, 2012, New York, NY: Beach Lane Books. Cover art copyright 2012 by Robert Neubecker.

To evaluate argumentation based primarily on the text, I use a combination of criteria from awards designed to address a point of view or perspective [e.g., Jane Addams Peace Award (http://www.janeaddamspeace.org/jacba/subguide.shtml), Scott O'Dell Award for Historical Fiction (http://www.scottodell.com/pages/scotto'dellawardforhistoricalfiction.aspx), Sibert Medal (http://www.ala.org/alsc/awardsgrants/bookmedia/sibertmedal/sibertterms/sibertmedaltrms) and the Orbis Pictus Award (http://www.ncte.org/awards/orbispictus)].

- Depending on the book, one or more of these criteria apply:

- Establishes a central claim;

- Provides clear and accurate evidence to support the claim;

- Appropriate organization with clear sequencing and logical development;

- Appropriate style of presentation for subject and for intended audience;

- Honest and intimate accounts of experience that are relevant.

If the argumentation is presented in the form of a picture book, or if it includes sufficient illustration, I use the following criteria from the Caldecott Medal as well (http:// www.ala.org/alsc/awardsgrants/bookmedia/caldecottmedal/caldecottterms/caldecottterms).

- Excellence of execution in the artistic technique employed;

- Excellence of pictorial interpretation of theme or argument;

- Appropriateness of style of illustration to the theme or argument;

- Delineation of argument through the pictures;

- Excellence of presentation in recognition of the intended audience. 


\section{How To Eat A Poem}

Don't be polite.

Bite in.

Pick it up with your fingers and lick the juice that may run down your chin.

It is ready and ripe now, whenever you are.

You do not need a knife or fork or spoon or plate or napkin or tablecloth.

For there is no core

or stem

or rind

or pit

or seed

or skin

to throw away.

(Eve Merriam, 1964) 
Just because poetry is written for children does not mean it will be fluffy and light. In Eve Merriam's poem, How To Eat a Poem, she doesn't condescend to readers with simplistic language or forced rhyme. She describes poetry through a metaphor that is easily relatable (eating) but also quite deep-a poem leaves nothing to throw away. She also portrays poetry as delicious, sloppy, and ill-mannered, sending readers the message that youthful interactions are encouraged.

The content of children's poetry spans the gamut of human experience-just like adult poetry. Also, the language of children's poetry varies depending on the intended audience. Poetry for young children (Figure 10.9) is different than poetry for older children (Figure 10.10); and poetry for older children is different than poetry for adolescents (Figure 10.11).

In US schools and universities, there is always the temptation to continue a structural approach to poetry. Analysis is familiar. Close reading is scholarly. Familiarity is the reason why the general public calls for a return "back to basics." Identifying the mechanics of a poem is one way people make sense of poetry. However, the elaboration, sensory detail, and descriptive language of poetry creates spaces for different ways to find meaning. I like to go into those spaces.

In this chapter, I explore who's writing poetic texts looking specifically at the content of poetry and examining texts that describe, persuade, and elicit embodied ways of reading.

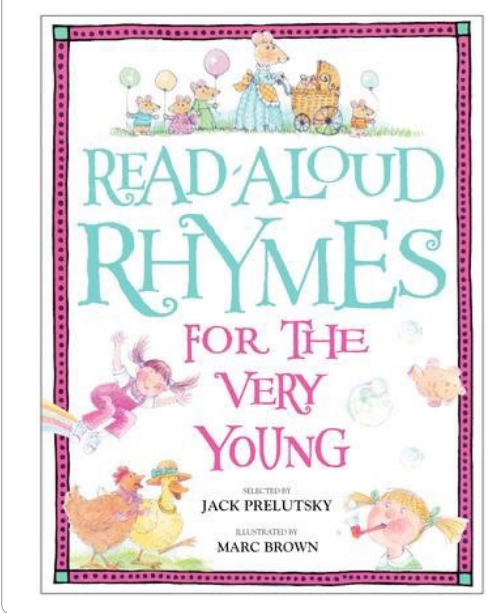

Figure 10.9

Poetry for very young children is playful and features rhyme, repetition, and memorable illustrations. Read Aloud Rhymes for the Very Young, written and selected by Jack Prelutsky and illustrated by Marc Brown, 1986, New York, NY: Knopf Books for Young Readers. Cover art copyright 1986 by Marc Brown.

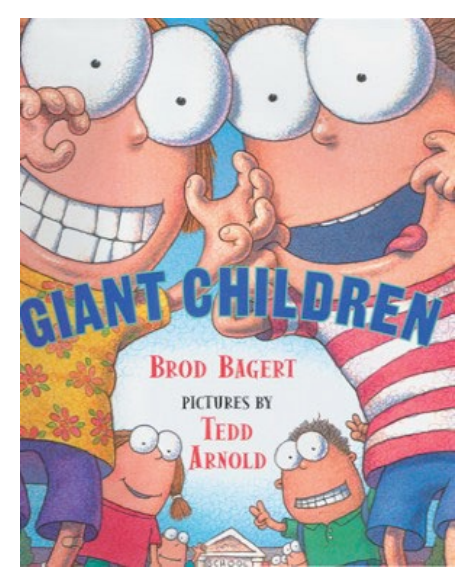

Figure 10.10

Poetry for older children reflects their growing sense of themselves and their world. Giant Children by Brod Bagert and illustrated by Ted Arnold, 2005, New York, NY: Puffin Books. Cover art copyright 2005 by Ted Arnold.

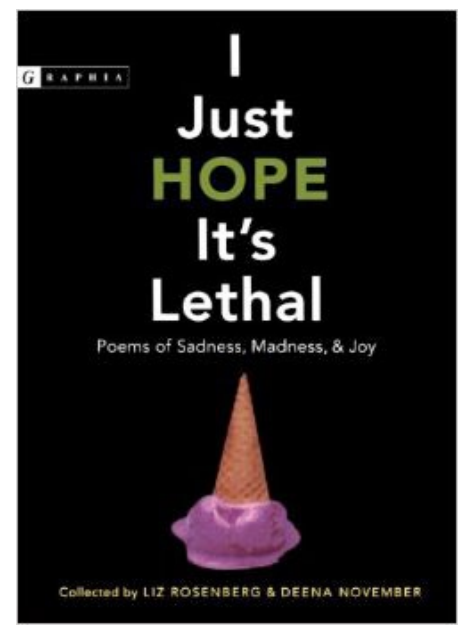

Figure 10.11

Poetry for young adults covers content that reflects their emotional range and the angst of adolescence. I Just Hope It's Lethal selected by Liz Rosenberg and Deena November, 2005, New York, NY: HMH Books for Young Readers. Copyright 2005 by Liz Rosenberg and Deena November. 


\section{Who's Who?}

When searching for lists of "best" poetry or the "top ten poets" of all time, why do the search results look like a collection from the Dead Poet's Society (Schulman, 1988)? Try to find a good list of recommended poets or poems and the lists are more classic than contemporary.

Here is a list of 30 Great Poems Everyone Should Know: http://www.thetimes.co.uk/tto/public/poetrycompetition/article3229711.ece

These poems come from poets who qualify for membership in the "Dead Poets Society." However, if you watch the film, the teacher, Mr. Keating (played by the late Robin Williams), challenges the orthodox, academic view on poetry:

"We don't read and write poetry because it's cute. We read and write poetry because we are members of the human race. And the human race is filled with passion. Medicine, law, business, engineering, these are all noble pursuits, and necessary to sustain life. But poetry, beauty, romance, love, these are what we stay alive for."

Then Mr. Keating lowers his voice and paraphrases Walt Whitman's poem, reciting: "O me, o life of the questions of these recurring, of the endless trains of the faithless, of cities filled with the foolish. What good amid these, o me, o lif Answer: that you are here. That life exists, and identity. That the powerful play goes on, and you may contribute a verse..." Then the Mr. Keating stops for a brief moment, looks at his students and asks, "What will your verse be?"

(Haft, et. al., 2006, Touchstone Home Entertainment).

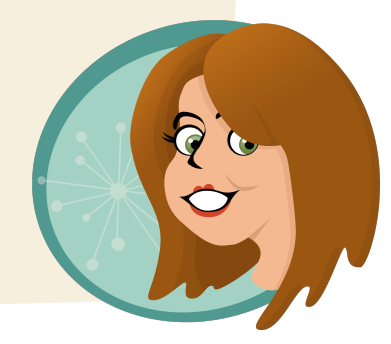

If you want to find a strong selection of poetry, you have to visit a public library or independent bookstore. Or you have to know specific titles and poets. Most adults' unfamiliarity with modern poetry creates a perpetual void in what is offered to youth. If parents, librarians, and teachers do not read or value poetry, then children are not exposed to poetry. In addition, I am frequently dismayed by the utter lack of poetry in major bookstores and retailers. In major retailers you will only find the most popular books based on sales history or holiday themes. It's true. Look for yourself. 


\section{The Popular Ones: Shel Silverstein, Jack Prelutsky}

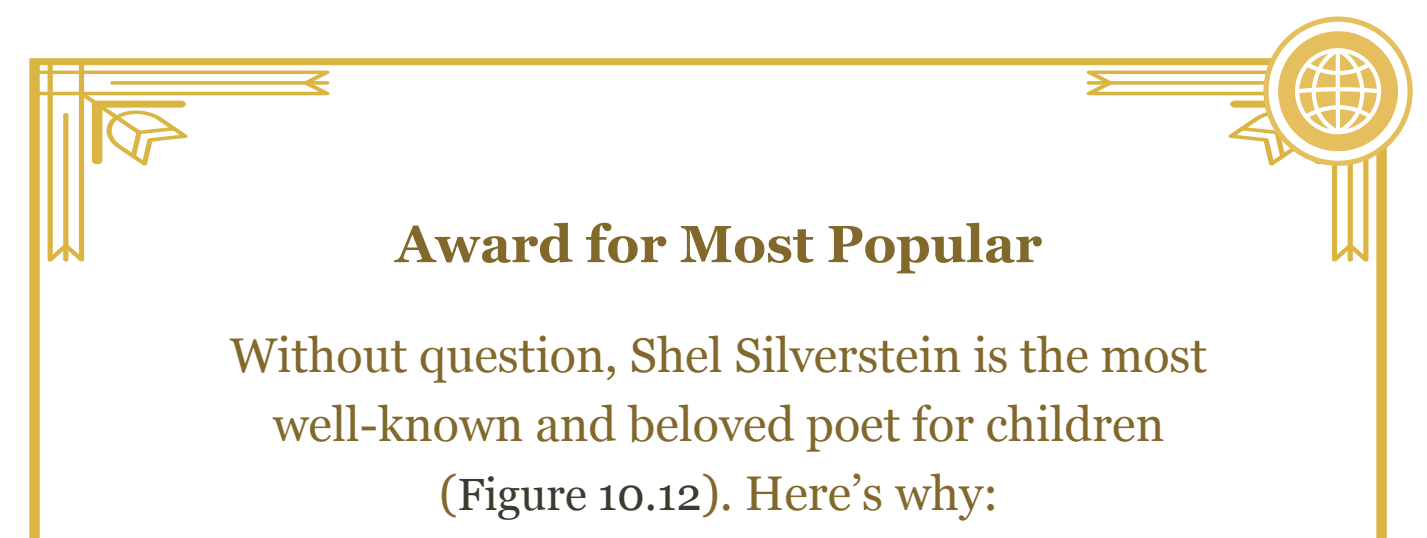

Shel Silverstein wrote poetry that entertains.

Watch him:

(https://www.youtube.com/watch?v=Bv2LUva-foo)

Shel Silverstein wrote poetry that is relatable.

Read Sick (https://www.poets.org/poetsorg/poem/sick).

Shel Silverstein wrote poetry that is meaningful. Read

The Little Boy and the Old Man

(http://poems.writers-network.com/shel-silverstein/the-

little-boy-and-the-old-man.html).

Shel Silverstein wrote poetry that sounds good

(Figure 10.13).

Shel Silverstein did not condescend to children.

Although some librarians and teachers critique his poetry as simplistic (e.g., Kutiper \& Wilson, 1993), he actually wrote from a playful, ironic, truthful place.

Shel Silverstein understood what children wanted and needed in a poem.

Plus, listen to him read

(https://www.youtube.com/watch?v=CNiaYHZme_U).

He knows how language works.

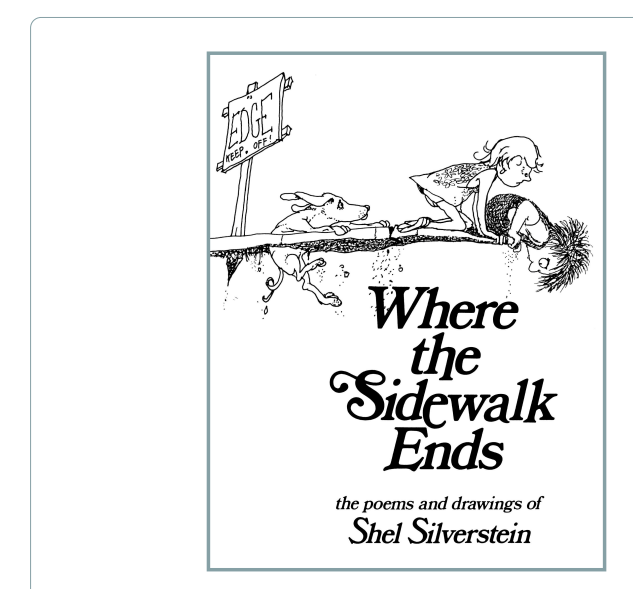

Figure 10.12

Where the Sidewalk Ends is a standard book in any library collection. Where the Sidewalk Ends by Shel Silverstein, 1974, New York, NY: Harper \& Row. Copyright 1974 by Shel Silverstein.

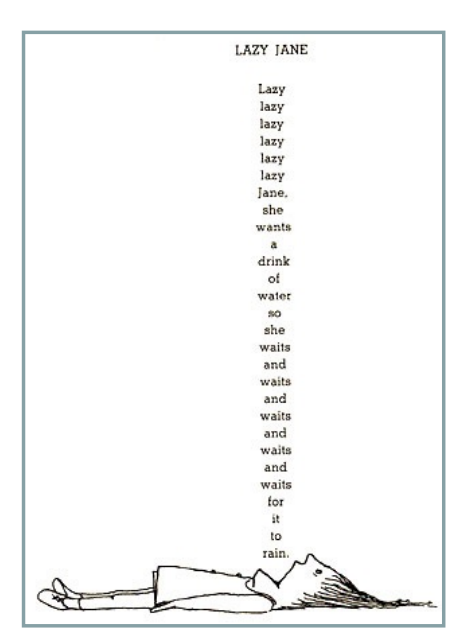

Figure 10.13

Shel Silverstein drew his own illustrations so he used words and images to create the sound, feel, and mood with which he wanted his poems read. "Lazy Jane" from Where the Sidewalk Ends by Shel Silverstein, 1974, New York, NY: Harper \& Row. Copyright 1974 by Shel Silverstein. 


\section{Award for Funniest \\ Jack Prelutsky shares similar qualities with Shel Silverstein.}

Jack Prelutsky writes poetry that entertains.

Watch this

(https://www.youtube.com/watch?v=nVJX845OLuA).

Jack Prelutsky writes poetry that is relatable.

\section{Read The Bogeyman}

(http://www.poetryfoundation.org/poem/177559).

Jack Prelutsky writes poetry that is meaningful

(Figure 10.14).

Jack Prelutsky writes poetry that sounds good.

Read here: (http://jackprelutsky.com/jacks-poems/).

Watch here: Jack reads at 08:50

(http://www.loc.gov/today/cyberlc/feature_wdesc.php? $\underline{\text { rec }}=4187$ ).

I love the poetry of Jack Prelutsky. Poetry doesn't need iambic pentameter or linguistic metaphors to impress me (although Jack has both). Prelutsky's poetry is mostly humorous; and who doesn't like humor? Plus, children and young adults love it (Figure 10.15).

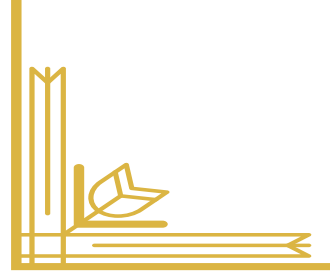

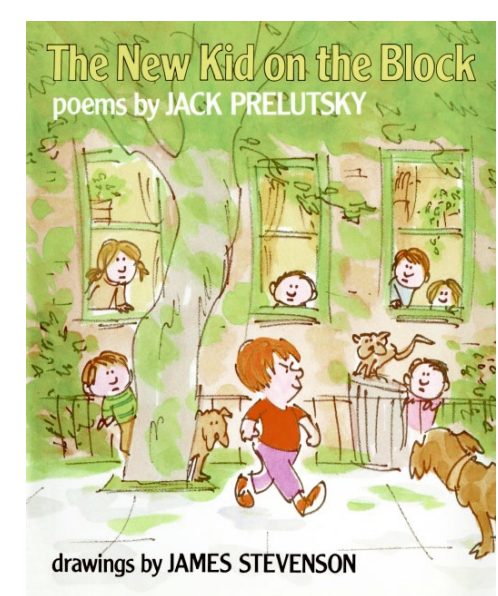

Figure 10.14

Have you ever been the victim of a bully? Jack Prelutsky knows how it feels. The New Kid on the Block by Jack Prelutsky and illustrated by James Stevenson, 1984, New York, NY: Greenwillow. Cover art copyright 1984 by James Stevenson.

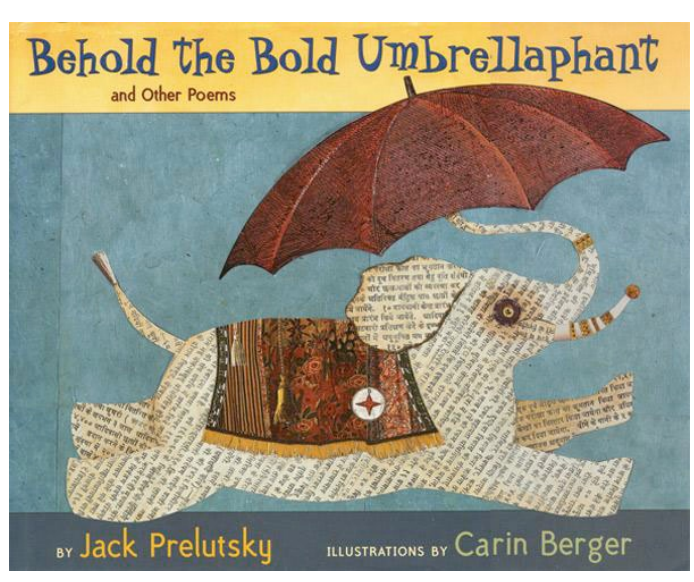

Figure 10.15

As demonstrated by the title of this book, Jack Prelutsky likes to play with the meaning and sound of words. Plus, he makes up words too. Behold the Bold Umbrellaphant by Jack Prelutsky and illustrated by Carin Berger, 2006, New York, NY: Greenwillow. Cover art copyright 2006 by Carin Berger. 
When selecting poetry for children, the popular poets, such as Jack Prelutsky and Shel Silverstein, are a great place to start. Why? Youth are drawn to their humor.

Way back in 1974, Ann Terry surveyed 422 students in 4th, 5th, and 6th grade to determine their poetry preferences. She found that the students liked contemporary poems with humorous content, familiar experiences, and animals (Sounds about right!). The students also preferred narrative poems and poems with rhythm and rhyme (Yes, they sound better). Students disliked the poems they couldn't understand (Who doesn't?) and they disliked poems with visual imagery and figurative language (I get it).

Follow-up studies in the early 1990 s supported Ann Terry's research. Kutiper and Wilson (1993) examined surveys of students in different grade levels and they also examined research using circulation records to determine what books students checked out of the library. The students consistently preferred rhythm, rhyme, excitement, and humor.

Recently, Jonda McNair (2012) found some expansion in children's interest in poetic forms (e.g., children enjoyed free verse), but the content of poetry preferences still holds true: youth like humorous, familiar, and rhythmic poetry. For these reasons, and many more, Uncle Shelby and Jackie P. are two of children's most loved poets.

Hmm, contemporary topics, familiar experiences, humor. Sounds like a perfect description of "Charge of the Light Brigade.” (Are you detecting my sarcasm?)

\section{The Award Winners}

In previous chapters, I debated the value of using awards to determine the quality of a book. Awards have their issues, but they also have some benefits. In the case of poetry, given its limited availability in bookstores, award winners are helpful guides that can direct your attention to the good stuff. 
The National Council of Teachers of English offers the Award for Excellence in Poetry for Children. This award was created in 1977 to honor a living American poet for his or her aggregate work for children ages 3-13. The award is given to a poet or anthologist (someone who creates poetry collections) for his or her literary merit, contributions, and appeal to children.

NCTE defines literary merit and appeal to children in the following way:

\section{Literary Merit (art and craft of aggregate work--as poet or anthologist)}

Creating books of poetry that demonstrate imagination, authenticity of voice, evidence of a strong persona, and universality / timelessness are essential. In short, we're looking for a poet who creates poetry books that contain clean, spare lines; use language and form in fresh ways; surprise the reader by using syntax artistically; excite the reader's imagination with keen perceptions and sharp images; touch the reader's emotions. A maker of word events is what we're looking for.

\section{Appeal to Children}

Although the appeal to children of a poet's or anthologist's work is an important consideration, the art and craft must be the primary criterion for evaluation. Evidence of students' excitement for the poetry and evidence of childlike quality, yet poem's potential for stirring fresh insights and feelings should be apparent. http://www.ncte.org/awards/poetry

The poets who won this award are among the who's who in children's poetry. Below, I listed the year they won the award and links to their collections via Goodreads.com (if available). Goodreads is a quick way to scan through most of their books.

- David McCord, 1977 (Figure 10.16)

(http://www.goodreads.com/author/show/ 6883654.David_T_W_McCord)

- Aileen Fisher, 1978 (http://www.goodreads.com/search?utf8=\%E2\%9C\% 93\&query=aileen+fisher)

- Karla Kuskin, 1979 (http://www.goodreads.com/ search?utf8=\%E2\%9C\%93\&q=karla +kuskin\&search_type=books)

Figure 10.16

David McCord won the first NCTE Award for Excellence in Poetry for Children. Every Time I Climb a Tree includes 25 memorable poems and engaging illustrations. Every Time I Climb a Tree by David McCord and illustrated by Marc Simont, 1967, New York, NY: Little, Brown and Company. Cover art copyright 1967 by Marc Simont. 
- Myra Cohn Livingston, 1980 (http://www.goodreads.com/search?utf8=\%E2\%9C\%93\&query=myra + cohn+livingston)

- Eve Merriam, 1981 (http://www.goodreads.com/search?utf8=\%E2\%9C\%93\&query=eve+merriam)

- John Ciardi, 1982 (http://www.goodreads.com/search?utf8=\%E2\%9C\%93\&query=john+ciardi)

- Lillian Moore, 1985 (http://www.goodreads.com/search?utf8=\%E2\%9C\%93\&q=lilian + moore\&search type=books)

- Arnold Adoff, 1988 (http://www.goodreads.com/search?utf8=\%E2\%9C\%93\&q=arnold + adoff\&search_type=books)

- Valerie Worth, 1991 (http://www.goodreads.com/search?utf8=\%E2\%9C\%93\&q=valerie +worth\&search type=books)

\section{- Barbara Juster Esbensen, 1994}

(http://www.goodreads.com/search?utf8=\%E2\%9C\%93\&q=barbara+juster+esbensen\&search_type=books)

- Eloise Greenfield, 1997 (Figure 10.17)

(http://www.goodreads.com/search?utf8=\%E2\%9C\%93\&q=eloise+greenfield\&search_type=books)

As a child, I always wondered about love. What is love? How do you know when you are in love? (Figure 10.17). In these poems, Eloise Greenfield uses very small moments from normal, everyday life, to show children what love means, how it feels, and how someone-who-loves acts.

\section{Love Don't Mean}

Love don't mean all that kissing

Like on television

Love means Daddy

Saying keep your mama company

till I get back

And me doing it.

\section{Keepsake}

Before Mrs. Williams died

She told Mr. Williams

When he gets home

To get a nickel out of her

Navy blue pocket book

And give it to her

Sweet little gingerbread girl

That's me

I ain't never going to spend it

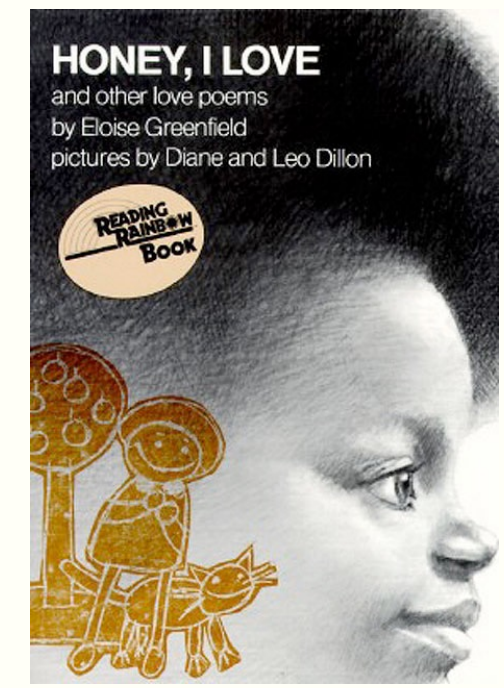

Figure 10.17

Eloise Greenfield wrote my two favorite love poems in Honey, I Love and Other Poems by Eloise Greenfield, illustrations by Diane and Leo Dillon, from Harper Collins Publishers, NY, 1978. Cover art copyright 1978 by Diane and Leo Dillon. 
- X.J. Kennedy, 2000 (http://www.goodreads.com/search?utf8=\%E2\%9C\%93\&q=x.j. +kennedy\&search type=books)

- Mary Ann Hoberman, 2003 (http://www.goodreads.com/search?utf8=\%E2\%9C\%93\&q=mary+ann thoberman\&search type=books)

- Nikki Grimes, 2006 (http://www.goodreads.com/search?utf8=\%E2\%9C\%93\&q=nikki tgrimes\&search type=books)

- Lee Bennett Hopkins, 2009 (http://www.goodreads.com/search?utf8=\%E2\%9C\%93\&q=lee+bennett thopkins\&search type=books)

- J. Patrick Lewis, 2011 (Figure 10.18)

(http://www.goodreads.com/search?utf8=\%E2\%9C\%93\&q=j. \pm patrick+lewis\&search type=books)

- Joyce Sidman, 2013

(http://www.goodreads.com/search?utf8=\%E2\%9C $\% 93 \& q=$ joyce + sidman\&search_type=books)

- Marilyn Singer, 2015 (http://www.goodreads.com/search? utf8=\%E2\%9C\%93\&q=marilyn+singer\&search_type=books)

The NCTE Award winners are not an exhaustive list of poets; but the list provides a good resource for exploration.

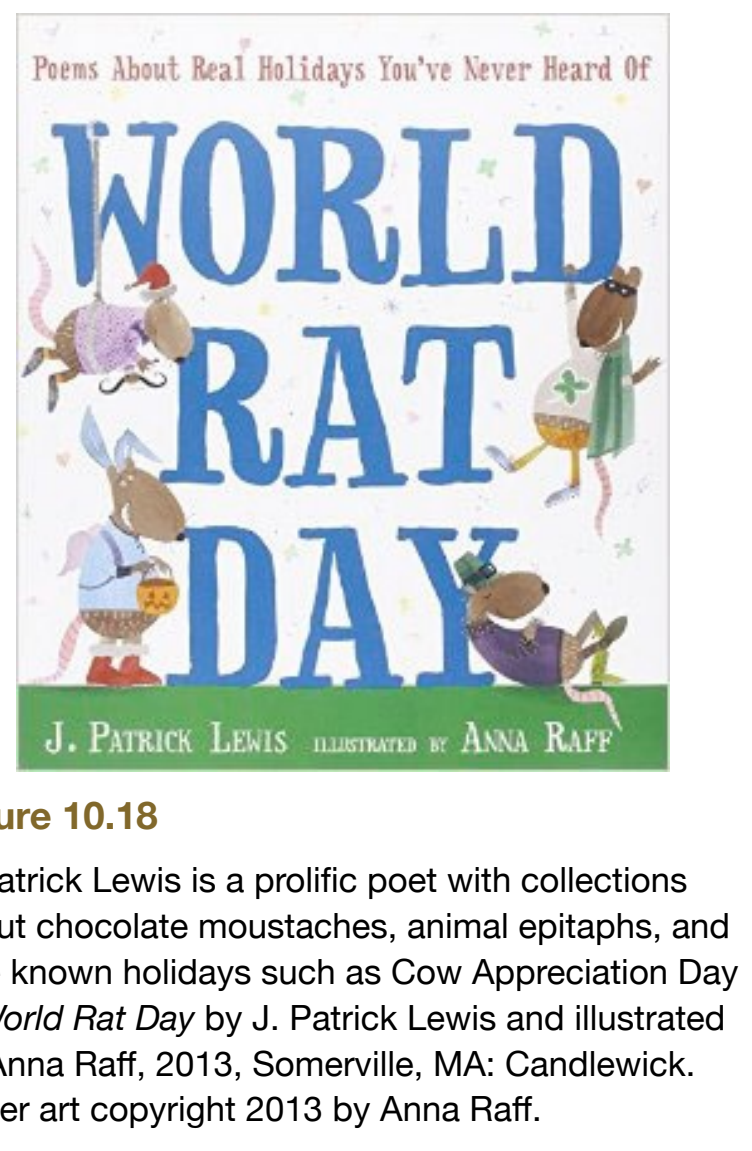

Another place to find award-winning poets is the list of Poet Laureates (http://www.loc.gov/ poetry/laureate-2011-present.html). The Poet Laureate is a consultant in poetry to the Library of Congress. The poet is appointed for a year term and the person is responsible for raising "the national consciousness to a greater appreciation of the reading and writing of poetry" (http:// www.loc.gov/poetry/about_laureate.html). The selected poets initiate special projects (e.g., Poetry $180 \mathrm{http}: / / \mathrm{www}$. loc.gov/poetry/180/) and engage in talks, readings, and dramatic performances. Of course, the Poet Laureates write poetry for adults, but many of them also write poetry for youth. In addition, the line between youth and adults is a blurry one. If the poetry inspires and interests you, it might do the same for children and young adults. 
There is no official Children's Poet Laureate for the Library of Congress. However, The Poetry Foundation awards the Young People's Poet Laureate title every two years (http:// www.poetryfoundation.org/resources/poet-laureate/). The award recognizes poets who write for children and youth, and it attempts to raise awareness and promote poetry for young people.

\section{The Weirdos, Novelties, and Outliers}

Between Shel, Jack, and the award winners, I've mentioned some of the big names in poetry for children. But there are many more. There are poets for every single taste and interestevery sense and sensibility.

Just for the fun of it, I categorized my favorite poets by their content. They are the weirdos, novelties, and outliers. I assign these labels with great affection. These poets have carved out poetry niches and they have moved the sound and look of poetry in new directions.

The Weirdos. The Weirdos are the poets who often write about scary, dark, and mysterious events. They may refer to a monster or two, including those that are imagined and real.

Roald Dahl (Figure 10.19)

Jack Prelutsky

Marilyn Singer

Christine Heppermann

Edgar Allan Poe

Liz Rosenberg

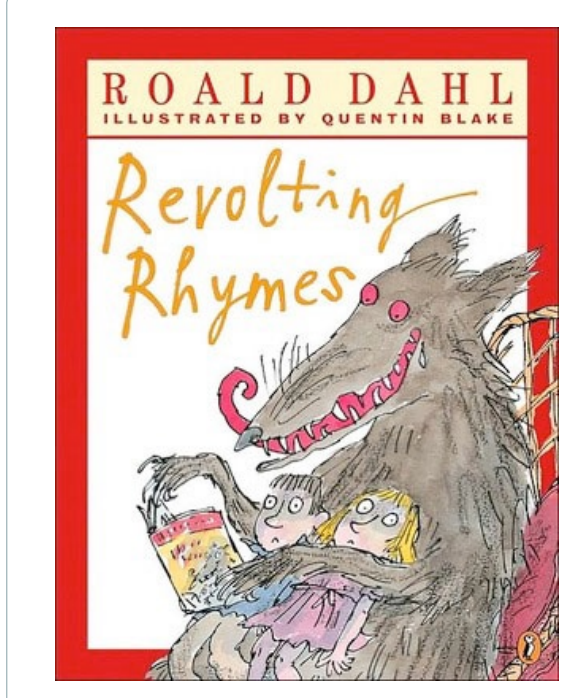

Figure 10.19

Roald Dahl is known for his fantasy novels, but he also liked to write wicked poetry. One example is Revolting Rhymes by Roald Dahl and illustrated by Quentin Blake, 1982, New York, NY: Alfred A. Knopf. Cover art copyright 1982 by Quentin Blake.

If you love scary, there is a website for scary poetry for children (http://www.scaryforkids.com/scary-poems/). If you can get past the ads and design, the poetry is good.

Poetry Soup also sorts poetry by scary type

(http://www.poetrysoup.com/poems/horror).

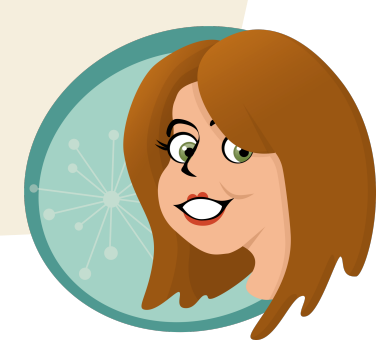


The Novelties. The Novelty poets are interesting and charming. They pursue their own topic strands and establish lines of poetry about school, lunchrooms, siblings, body functions, etc. They are the serial poets.

Bruce Lansky

Alison Lester

Dennis Lee

Natalie Finnigan

C.J. Heck

Kenn Nesbitt (Figure 10.20)

Brod Bagert

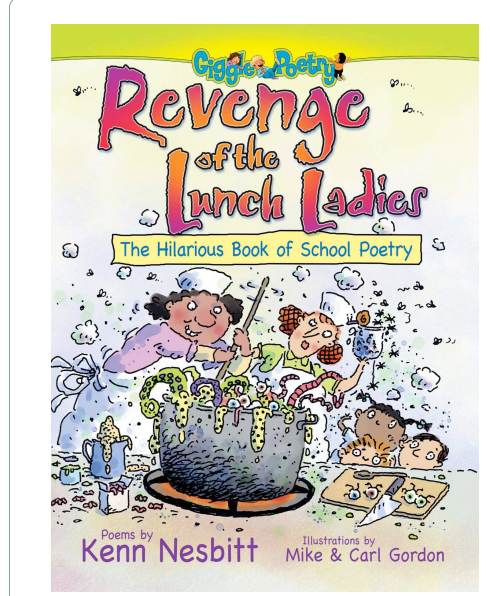

Figure 10.20

Kenn Nesbitt is a popular poet who typically publishes humorous poetry. One example is Revenge of the Lunch Ladies: The Hilarious Book of School Poetry by Kenn Nesbitt and illustrated by Mike Gordon and Carl Gordon, 2007, New York, NY: Meadowbrook. Cover art 2007 by Mike and Carl Gordon.

Kenn Nesbitt created a website where users can search for poems by category and reading level. The website also includes games, apps, word lists, and videos (http://www.poetry4kids.com).

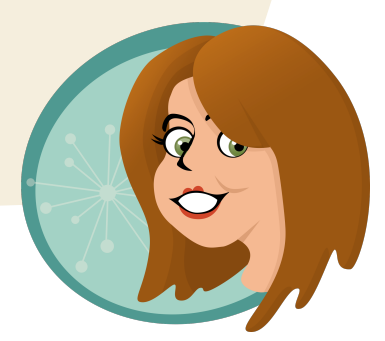

The Outliers. The Outliers are the poets who are unconventional. They are the poets who think with poetry and challenge the status quo. They write about social justice, food justice, and the environment. They explore our ways of being.

Paul Fleischman

Douglas Florian

Jacqueline Woodson

X.J. Kennedy

Paul Janeczko

Judith Viorst

Joyce Sidman

Naomi Shihab Nye (Figure 10.21)

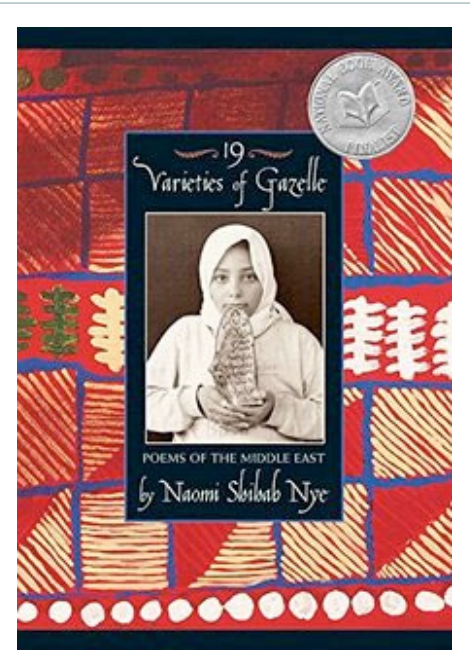

Figure 10.21

Naomi Shihab Nye received a lot of attention for her poetry for girls but she writes a broad range of poetry. 19 Varieties of Gazelle: Poems of the Middle East by Naomi Shihab Nye, 2002, New York, NY: HarperCollins. Copyright 2002 by Naomi Shihab Nye.

Jacqueline Woodson is the Young People's Poet Laureate from 2015-2017. Her website includes samples of poetry as memoir, poetry as fiction, poetry as picture book, poetry as history, and poetry as empathy (http://www.jacquelinewoodson.com/books-ive-written/poetry/).

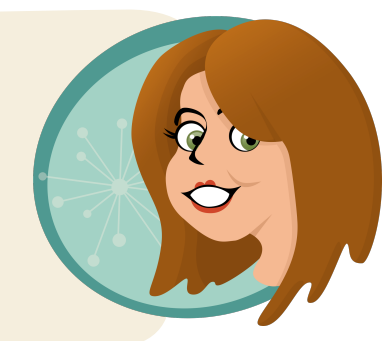


Whether popular, award-winning, or weird, poetry can be used to describe, inform, persuade, and tell stories. Poets describe human emotions and experiences, pushing readers toward new ways of thinking.

\section{Finding Poetry}

Quite honestly, poets are difficult to categorize and they rarely focus all of their writing efforts on one theme or a single form of poetry. For this reason poetry is often assembled into anthologies, featuring the work of many people.

- Anthologies are collections of poetry.

- Single-authored anthologies are collections of poetry by one poet (Figure 10.22).

- Edited anthologies are collections of poetry by many different poets and an editor makes the selection of which poets and what poems to include in the collection (Figure 10.23).

- Picture books are also used to showcase poetry collections (Figure 10.24).

- Single poems can be segmented to span the length of a picture book.

- Picture books are often used to showcase an illustrator's interpretation of poetry.

- Entire novels can be written in verse, with or without illustration (Figure 10.25).

Children's poetry comes in all shapes, sizes, and formats to cover any topic (Video 10.1). There are many poetry websites that make it easy to find poets and their poetry.

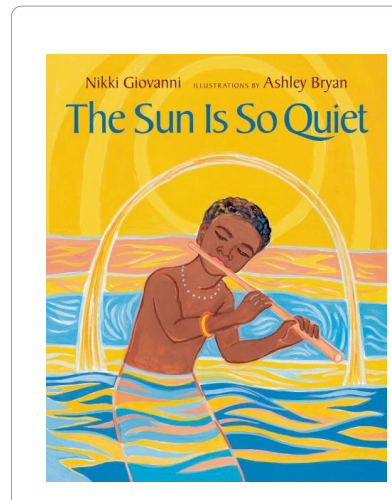

Figure 10.22

All of the poems in this book were written by Nikki Giovanni. Then Ashley Bryan created illustrations that integrate the text. The Sun Is So Quiet by Nikki Giovanni and illustrated by Ashley Bryan, 1996, New York, NY: Henry Holt and Co. Cover art copyright 1996 by Ashley Brya

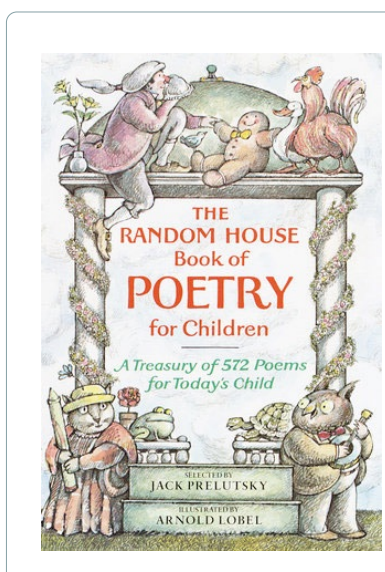

Figure 10.23

Jack Prelutsky edited my favorite poetry anthology of all time-The Random House Book of Poetry. Search for poetry by topic, title, author, and first line. There are poems about everything-from Abraham Lincoln to rainy days. It is a beautiful collection illustrated by Arnold Lobel. The Random House Book of Poetry for Young Children selected by Jack Prelutsky and illustrated by Arnold Lobel, 1983, New York, NY: Random House. Cover art copyright 1984 by Arnold Lobel.

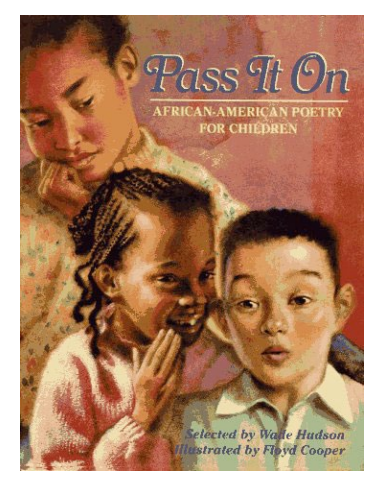

Figure 10.24

Collections, such as Pass It On, gather selections from poets who use their voices to point out injustice and to inspire people. Pass It On: African American Poetry for Children selected by Wade Hudson and illustrated by Floyd Cooper, 1993, New York, NY: Scholastic. Cover art copyright 1993 by Floyd Cooper.

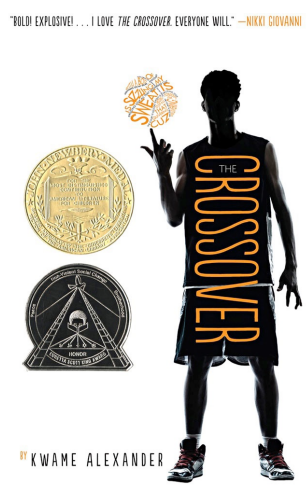

Figure 10.25

The Crossover is a verse novel, telling the story of Josh and JB, basketball and life. The Crossover by Kwame Alexander, 2014, New York, NY: Houghton Mifflin. Copyright 2014 by Kwame Alexander. 


\section{SURVEY OF POETRY}

\section{WITH JENIFER SCHNEIDER}

\section{THE INSIDE, OUTSIDE, AND UPSIDE DOWNS $\mid$ From Poets and Pop-ups to Princesses \\ OF CHILDREN'S LITERATURE and Porridge}

\section{For Extensive Biographies and Information About Poets:}

- The Poetry Foundation (http://www.poetryfoundation.org/children/) features children's poets, videos, articles, newsletters, and social media links about children's poetry.

\section{To Search For Complete Poems:}

- The Academy of American Poets provides a search tool to find poetry by occasion, theme, or form (https://www.poets.org/poetsorg/browse-poems-poets).

- Poem Hunter allows searchers to find poems and poets by title and theme (http://www.poemhunter.com).

- The Poetry Archive is a comprehensive, searchable website where you can find famous poets (http://childrenspoetryarchive.org/). 


\section{To Search "Best Of” Lists}

- This Goodreads collection features excellent examples of poetry for children and youth (http://www.goodreads.com/list/show/1340.Best_children_s_poetry books).

- The Public Broadcasting Service (PBS) compiled a list of top ten children's poets (http://www.pbs.org/parents/education/bookfinder/popular-poets-for-kids/).

- Here is another list that is more contemporary and diverse (http://www.buzzfeed.com/ krystieyandoli/life-changing-poems-everyone-should-read\#.laYZ2DnVw).

\section{Sharing Poetry}

With an understanding of who writes poetry, let's take a look at how to read and share poetry for children and youth.

\section{Poetry Is Not A Math Problem}

Poetry should NOT be

Structurally dissected

Linguistically torn apart

Or quantifiably syllabified

Without a focus on enjoyment, engagement, and reading.

Poetry should not be

Forcibly

Memorized

Or contrived to fit some outdated conception of literariness.

Children's poetry should be READ ALOUD!

Experienced.

Savored.

Acted upon. 


\section{Reading Aloud and Recitations}

Poetry readings are not a new concept. Poetry is best experienced when it is read aloud.

Poetic language is intended for savoring, enunciating, stretching, and emphasizing.

Reading aloud entertains children, youth, and adults.

Reading a shared text gives the group a central focus and a cohesive focal point.

Reading aloud elicits conversations and further insight about the poem.

Reading aloud helps children learn how to read (this is really true). They develop an ear for poetry, language, and words.

I couldn't understand Shakespeare until my high school English teacher read it out loud. Listen to Shel Silverstein, Maya Angelou, and Langston Hughes read their poems. Their reading techniques add to my comprehension of their messages.

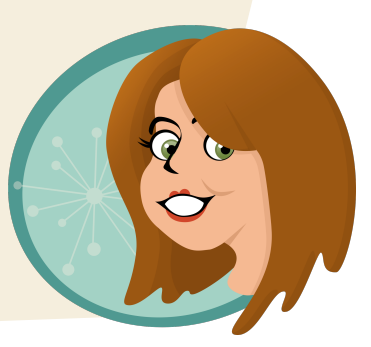

The web exhibit, Poetry Through The Ages, provides excellent suggestions for reading aloud (http://www.webexhibits.org/poetry/home reading.html). The exhibit also explains the basic measurements of poetic forms (e.g., hexameter, pentameter, etc.) and the most common types of meter used. In addition, the exhibit outlines tools for reading poetry.

Reading poetry is so important the Library of Congress developed Poetry 180 (http://www.loc.gov/poetry/180/), a resource intended to help high school students read a poem a day during the school year. Hosted by Billy Collins, U.S. Poet Laureate from 2001-2003, Poetry 180 includes a list of 180 poems (one for each school day), ideas for ways to share the poems, and helpful hints for how to read a poem effectively.

Read the poem slowly.

Read in a normal, relaxed tone.

Pause only where there is punctuation, not at the end of every line.

Know what the poem means so the message is communicated

(From http://www.loc.gov/poetry/180/p180-howtoread.html). 
For those who like competition, Poetry Out Loud is a national competition sponsored by the National Endowment for the Arts and the Poetry Foundation (http://www.poetryoutloud.org). The official contest is for high school students in participating states, but the poetry and materials are free for anyone to use. Poetry Out Loud also offers tips for reading and video examples of voice, physical presence, and dramatic appropriateness (http://www.poetryoutloud.org/poems-and-performance/tips-on-reciting).

\section{Choral Reading}

Choral reading or speaking is a term that describes an oral performance in which two or more people read or speak as one voice. Choral reading or speaking requires the performers to read for fluency and listen to the nuances of written language. In other words, through performance, the reader attends to the descriptive and structural elements of the text. Paul Fleischman created books of poetry for two voices (Figure 10.26) and four voices (Figure 10.27).

There are no specific criteria for selecting a text to read chorally. Instead, let the text determine the choral speaking method. Although poetry is perfect for choral speaking, not all poems are suitable for it. Choose your text carefully. Use the following general descriptions as a basis for your decisions.

Before you begin, read the poem once or twice to hear the flow of the language and understand the poem's meaning. Then use Poetry 180 for tips for reading effectively (From http://www.loc.gov/poetry/180/p180-howtoread.html).

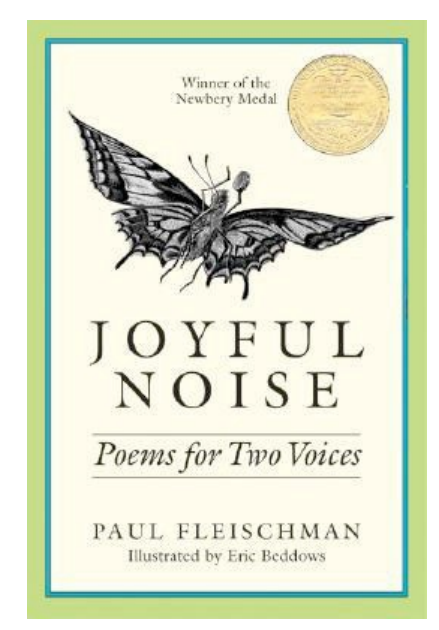

Figure 10.26

This book is quite remarkable. Joyful Noise tells the stories and secret lives of insects. The words are perfectly placed on the page, telling readers when to read alone or as two voices. Joyful Noise: Poems for Two Voices by Paul Fleischman and illustrated by Eric Beddows, 1988, New York, NY: Harper Trophy. Cover art copyright 1988 by Eric Beddows.

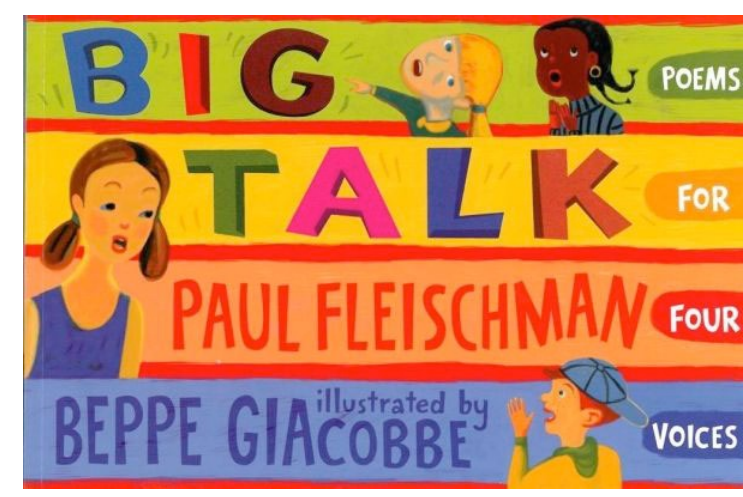

Figure 10.27

Paul Fleischman kicks it up a notch with poetry for four voices. The text and illustrations in Big Talk orchestrate choral reading. Big Talk: Poems for Four Voices by Paul Fleischman and illustrated by Beppe Giacobbe, 2008, Somerville, MA: Candlewick. Cover art copyright 2008 by Beppe Giacobbe. 
Refrain. Choose a text in which the refrain repeats and is important. Typically, a selected person reads most of the lines while other participants read lines or stanzas that repeat. Here is an example (Video 10.2).

Video 10.2 IGNTE Choral Reading:Speak FIRST Chapter https://www.youtube.com/watch?v=Cp-VTHGIKWA

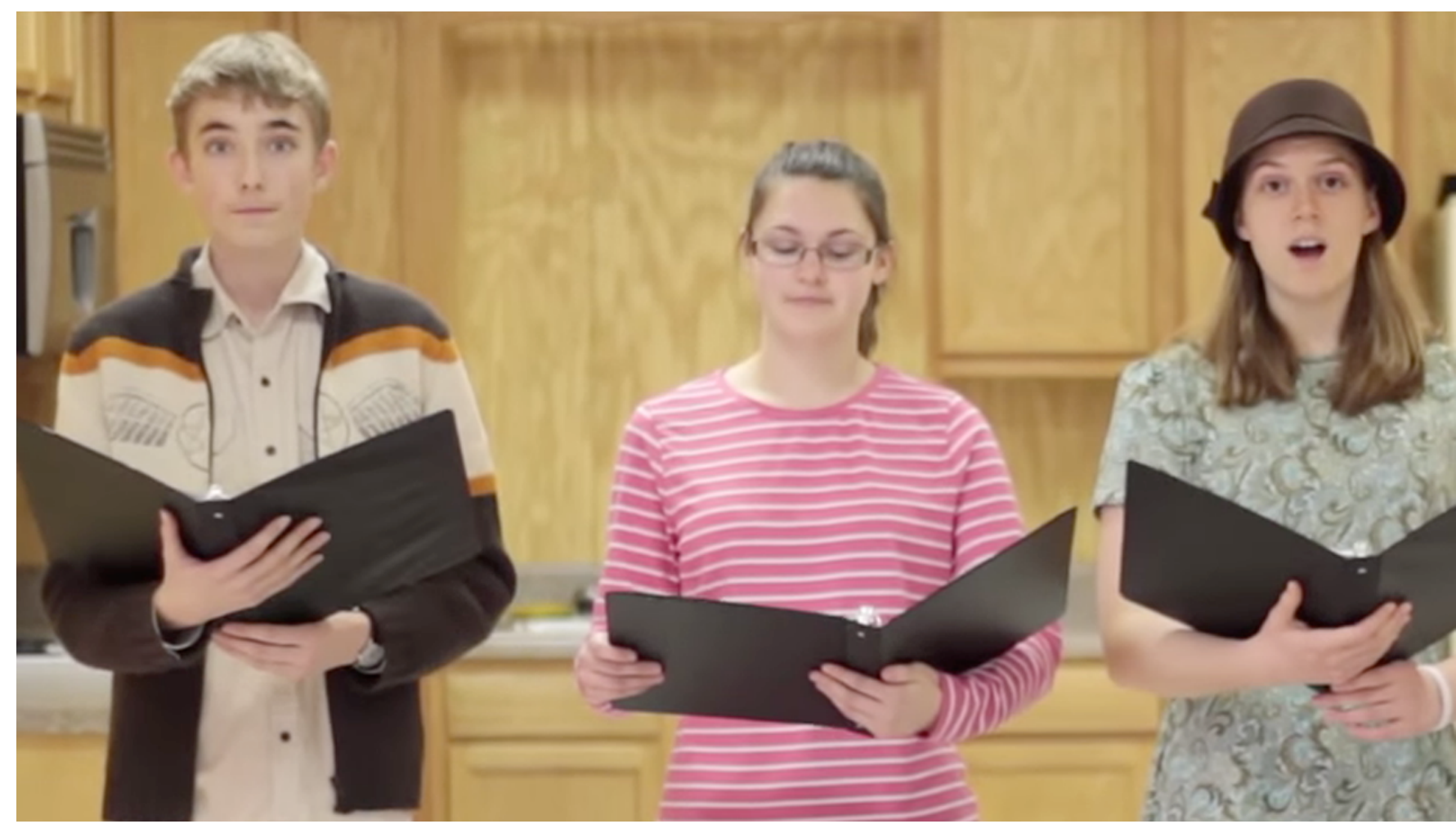

Line a person/group. Choose a text in which different voices need to be heard. Divide the text into segments (e.g., lines, stanzas, refrains). Individuals or small groups are assigned to read one segment. Each person reads only his or her segment. You may also assign small groups to read one segment. Here is an example (Video 10.3).

Video 10.3 Choral Reading Example https://www.youtube.com/watch?v=LFRzl2Oe_Bs

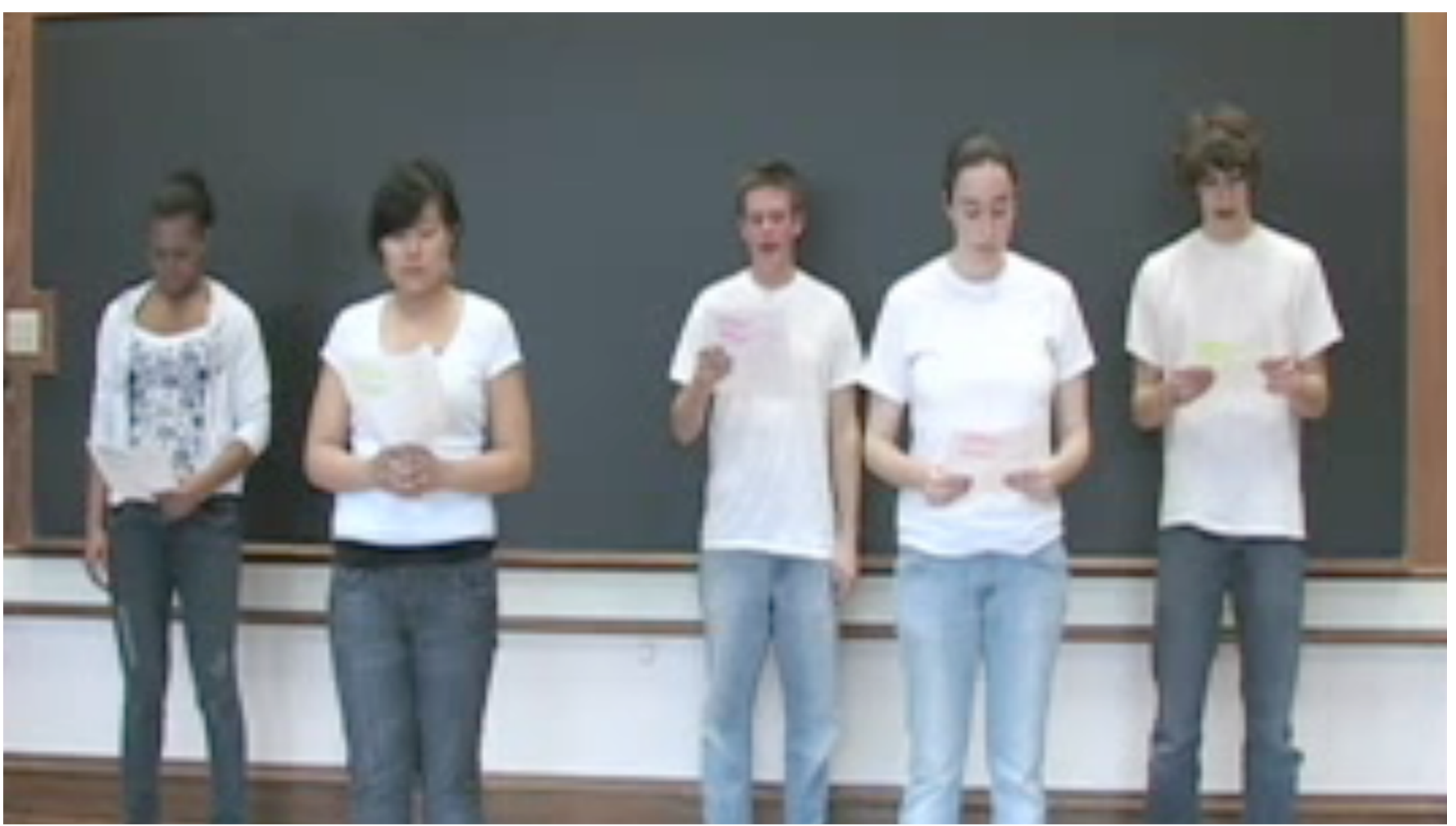


Here is another one (Video 10.4).

Video 10.4 Changing the World, One Word at a Time! https://www.youtube.com/watch?v=YshUDa10JYY

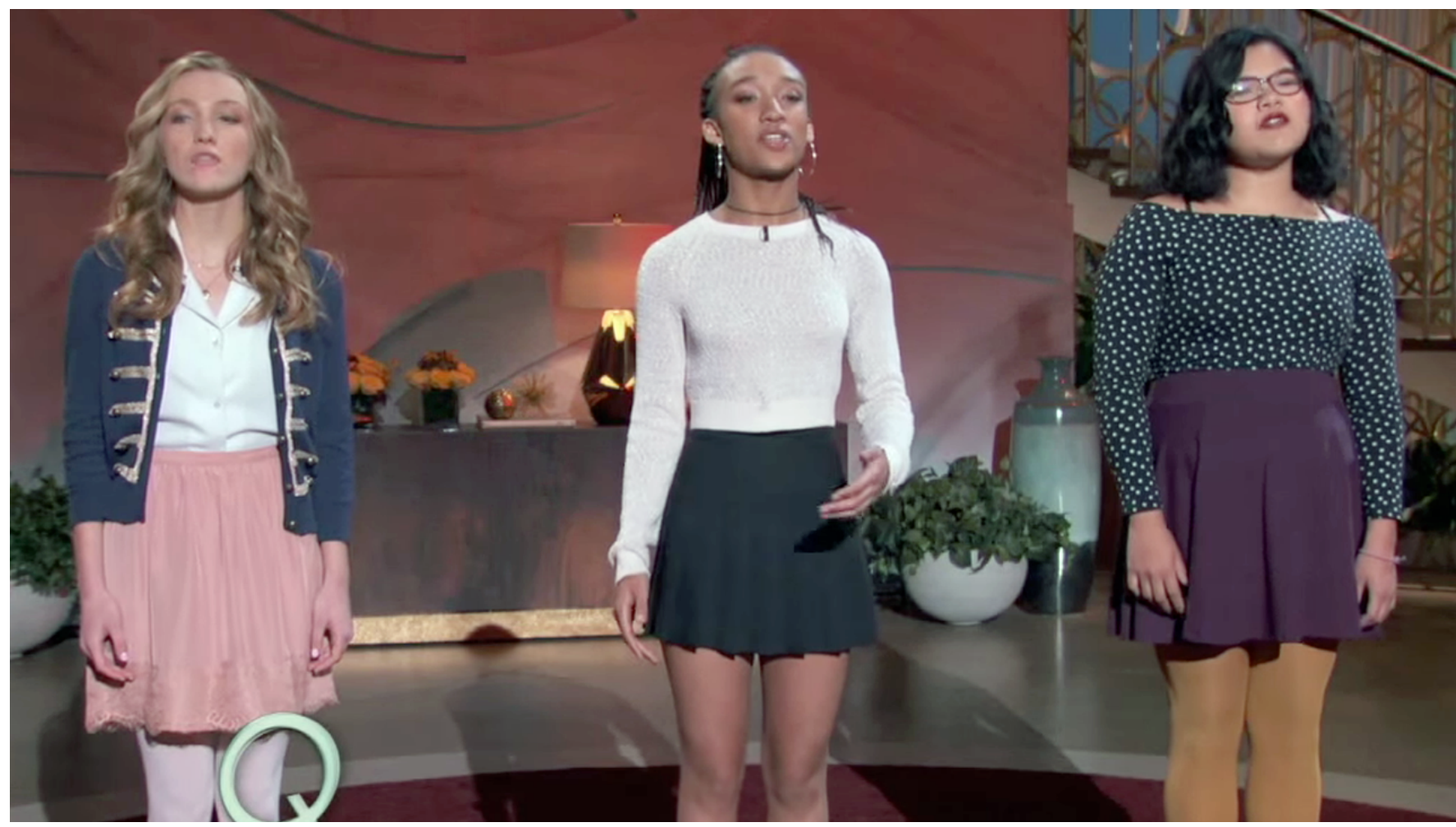

Cumulative. Choose a text in which the message builds or circles around concepts or phrases. Divide the poem into segments and assign to a person/group. The first reader begins and then others join in when it is their turn. Everyone reads his or her segment and continues reading until the end of the poem. Here is an example (Video 10.5).

Video 10.5 Old Lady Who Swallowed A Fly https://www.youtube.com/watch?v=qC_xO2aN_IA

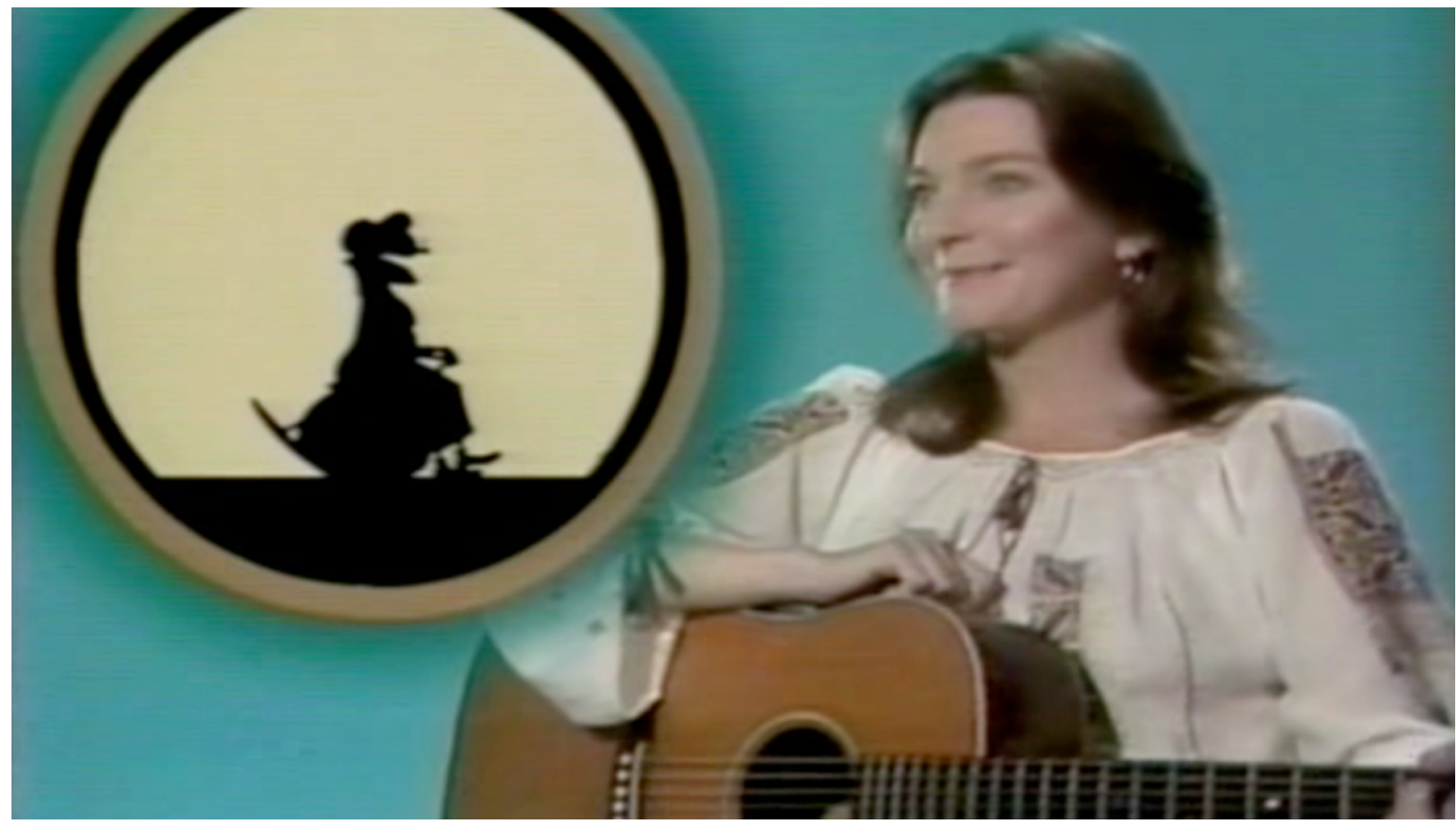


Here is another one (Video 10.6).

Video 10.6 Three Michael McDonalds Sing "Row, Row, Row Your Boat"

https://www.youtube.com/watch?v=JeCD4blkQwg

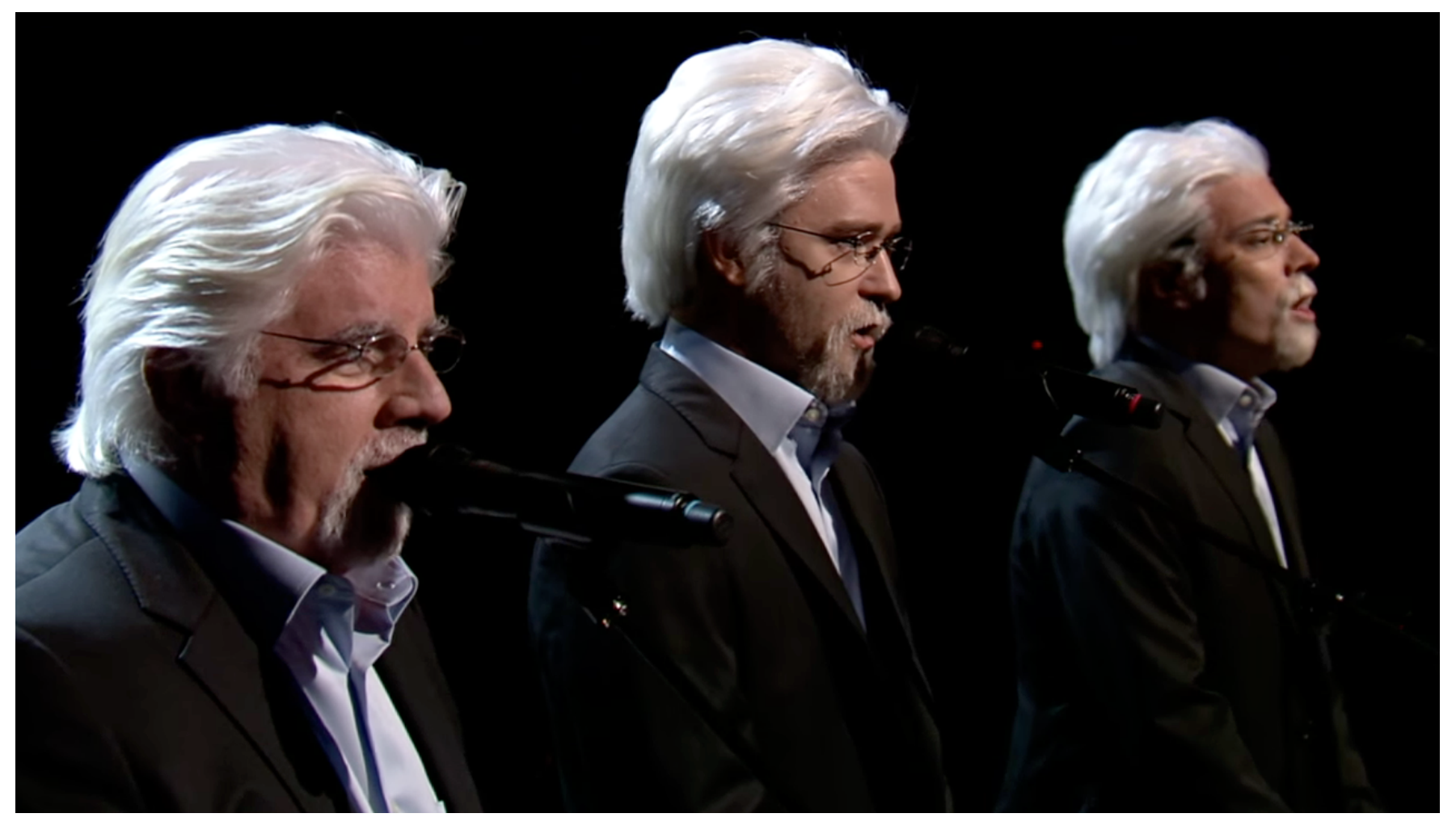

Antiphonal. Select a text in which the message is emphasized by different voices, tones, and sounds. Divide the text into segments and determine the "voice" for each segment (Ex. high-low, soft-loud, squeaky-strong, male-female, etc.). Then divide the group to read their corresponding parts. Here is an example (Video 10.7).

Video 10.7 IGNTE Choral Reading: 4th Chapter https://www.youtube.com/watch?v=gbtMDrxi9JY

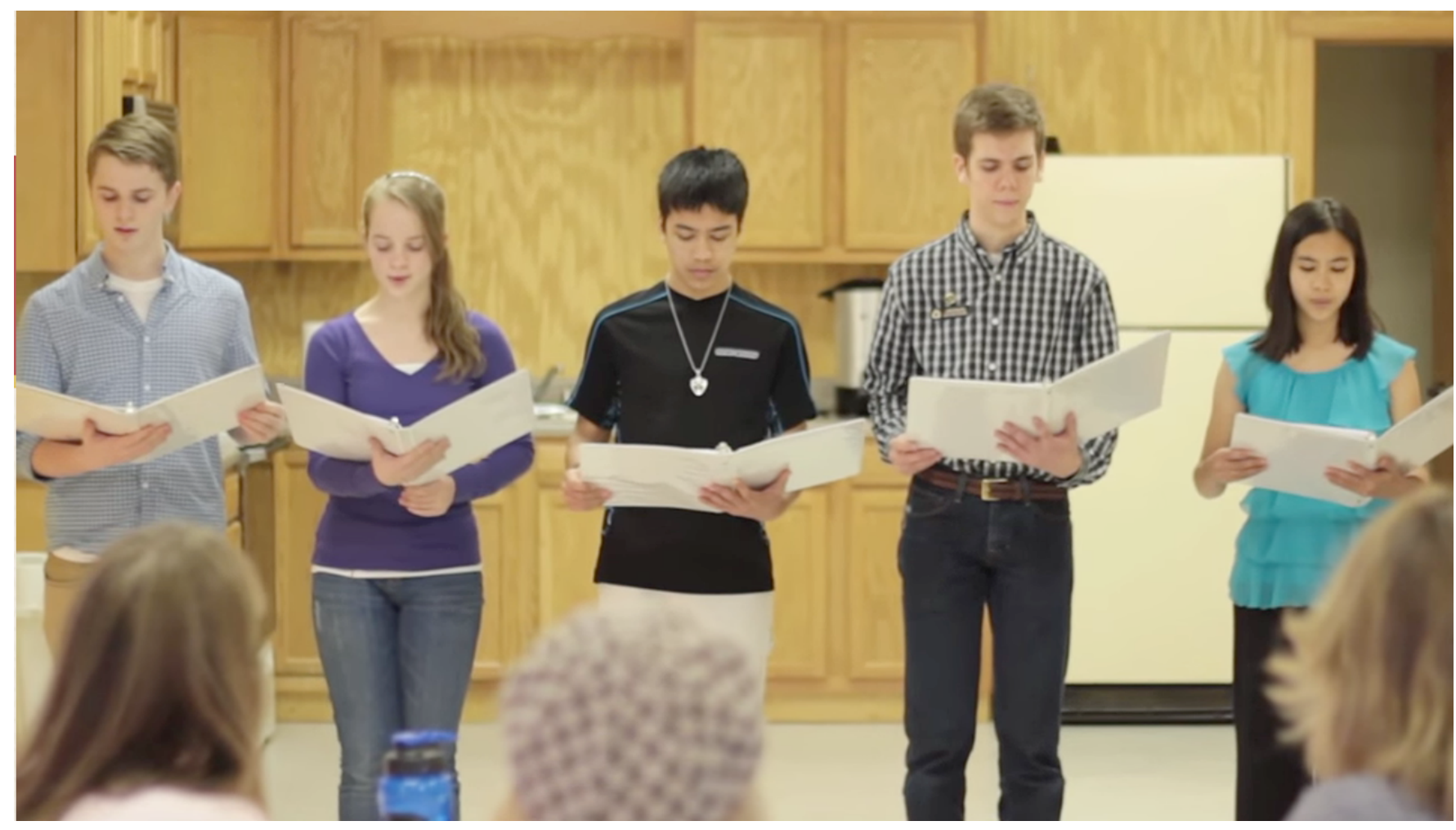


Unison. Choose a text that feels communal and more powerful when read by many voices. To me, unison reading is the most difficult type of choral speaking because the entire group reads the poem at one time. It takes practice to get many voices reading at the same time. Here is an example (Video 10.8).

Video 10.8 Valentine's Day Poem / Moon Whole Class https://www.youtube.com/watch?v=HJK2Lg5NfmM

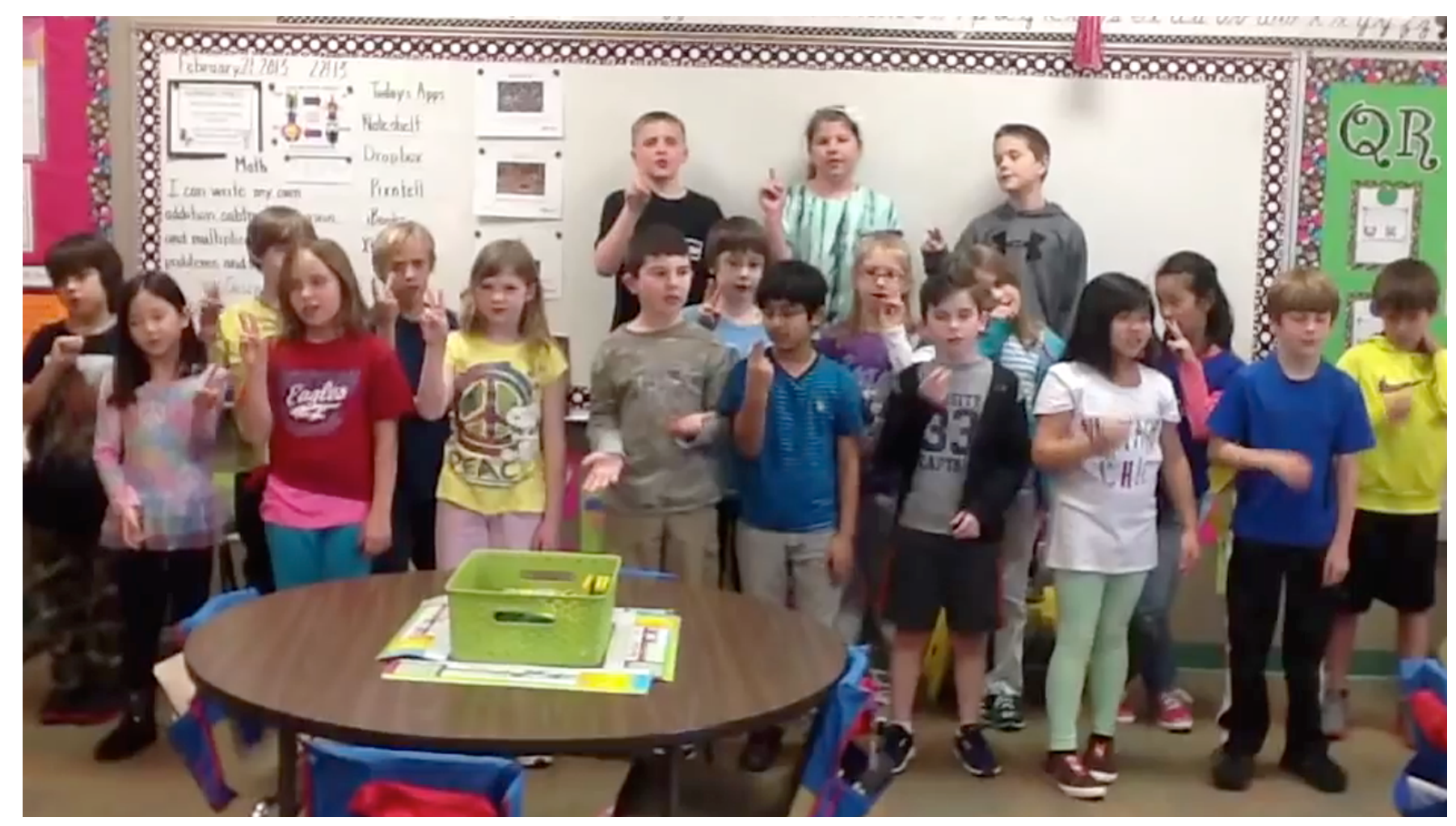

\section{Poetry Slams and Spoken Word}

Poetry Slams are performance opportunities for individuals or teams of poets to present their work on stage. Audience members and/or a panel of judges rate the performance and select winners. Poetry Slams are live events, but slams can also occur via social networks (https://www.youtube.com/watch?v=lpPASWlnZIA) and curated collections such as TED talks (https://www.youtube.com/watch?v=cxGWGohIXiw).

Watch this Ted Talk about writing slam poetry. http://ed.ted.com/lessons/become-a-slam-poet-in-five-steps-gayle-danley

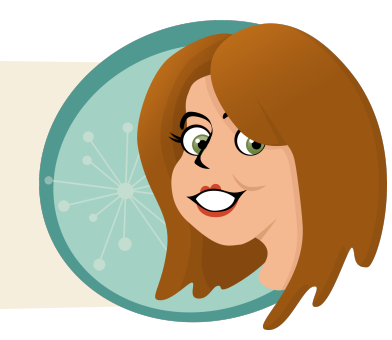


Youth Speaks (http://youthspeaks.org/) is an organization that produces local and national youth poetry slams, festivals, and reading events, as well as arts-education programming.

Spoken Word poetry is similar to a Poetry Slam in that the poetry is performed in front of an audience. However, there is no winner or contest. The Power Poetry website provides advice for writing and performing Spoken Word poetry (http://www.powerpoetry.org/actions/5-tips-spoken-word).

\section{Performing and Embodying Poetry}

In addition to sharing poetry through recitation and poetry slams, poetry is also a source for embodied performance. Poetic texts elicit different responses and emotions. To act on those responses, readers often use arts-based modalities as a way of understanding. In particular, performing arts allow readers to use their voices and body movements to convey their interpretations.

Recitation of poetry can be a good thing-with the right poem for the right reader at the right time. Here is someone who obviously loves the poems she memorized (https://www.youtube.com/watch?v=opg6BFDpJ4g).

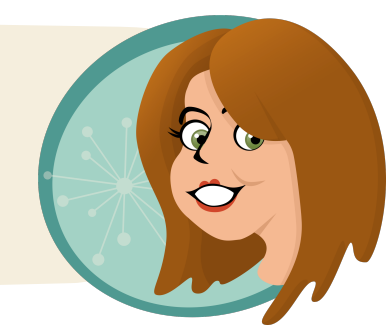

Dramatic interpretation. Dramatic engagement can take many forms, from a scripted play to an improvised scene. Poetic texts can serve as the foundation for dramatic performances or as the basis for informal theater games. For example, tableaux are frozen scenes created by participants' bodies, gestures, and facial expressions. Tableau can be used as a form of illustration as readers enact scenes with their bodies. Tableau also provides a structure in which the participants can explore characters, emotions, and roles from within the text (See Figures 10.28 and 10.29).
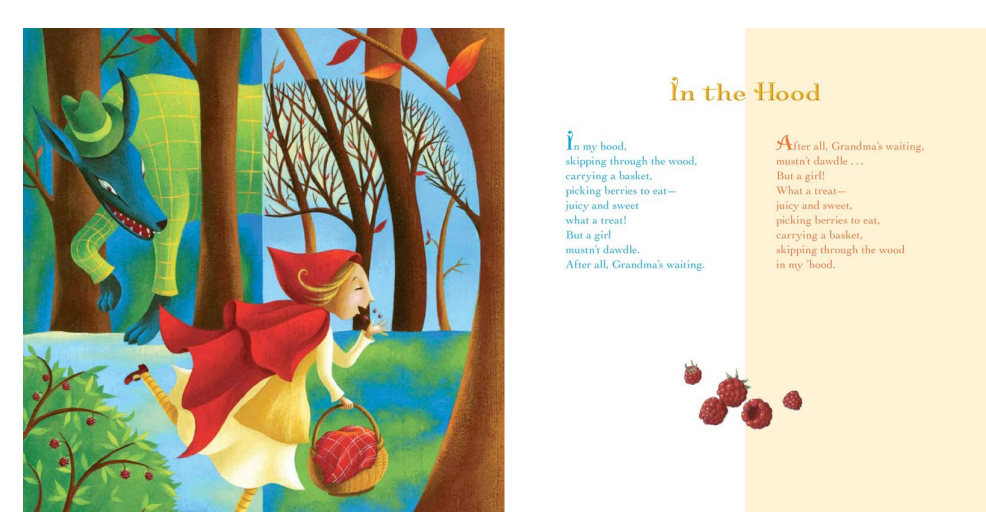

Figure 10.28

Marilyn Singer creates poetry that has one meaning when read down one side of the page and a different meaning when read on the other. Through this structure, she shares new perspectives on familiar fairy tales. Mirror Mirror: A Book of Reverso Poems by Marilyn Singer and illustrated by Josee Masse, 2010, New York, NY: Dutton. Cover art copyright 2010 by Josee Masse.

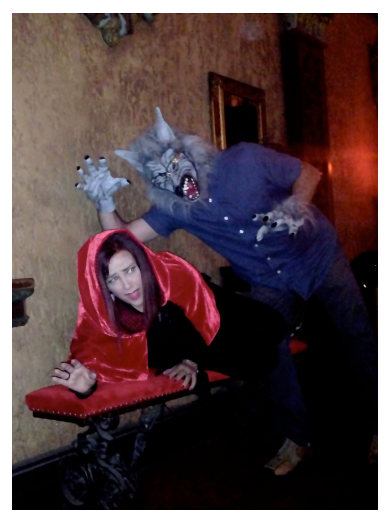

Figure 10.29

Tableau gives readers an opportunity to experience poetry from the characters' perspectives. In this frozen scene, the participants explore the perspectives of a girl and a wolf using the positions of their bodies, gestures, and facial expressions. Photo copyright 2014 by Randi Meyer. 
Musical interpretation. Musical performance is another medium for reading and sharing poetry because the poetry can be rhythmically, linguistically, and vocally interpreted. Many people equate song lyrics with poetry, but there may be more intricate connections with regard to content and sound (Figure 10.30). Musical instruments, including the voice, can be explored in relation to the rhythm, tone, and cadence of a poem. Watch this video for an excellent example of musical interpretation of poetry (Video 10.9).

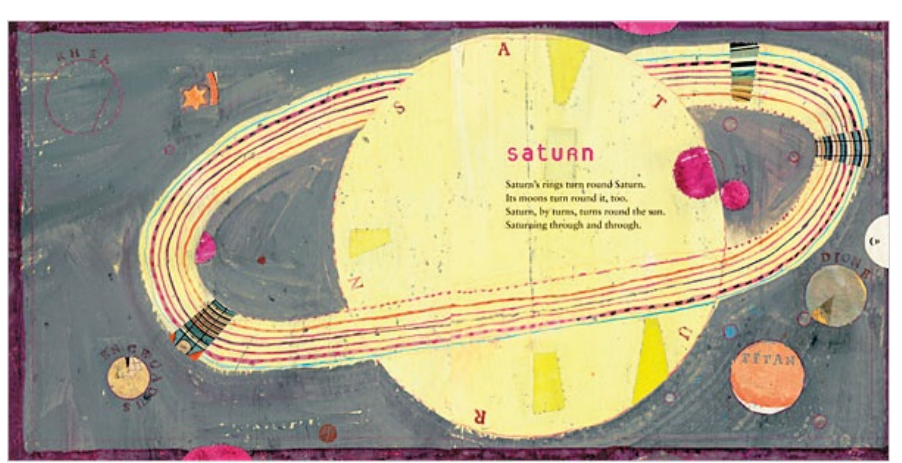

Figure 10.30

When a poet is also an illustrator, really cool things can happen between image and text. For example, Douglas Florian uses art to understand celestial objects and find just-right words to describe them. Image of Saturn from Comets, Stars, the Moon, and Mars by Douglas Florian, 2007, New York, NY: HMH Books for Young Readers. Copyright 2007 by Douglas Florian.

\section{PERFORMING A BOOK AT MULLER ELEMENTARY}

\section{WITH JENNIFER ROSS}

\section{THE INSIDE, OUTSIDE, AND UPSIDE DOWNS $\mid$ From Poets and Pop-ups to Princesses OF CHILDREN'S LITERATURE and Porridge}


Visual interpretation. If you explore children's poetry, you will discover that most publications contain visual elements, pictures, or nontraditional uses of typeface and layout. Consequently, many poems published for children are visual poems or presented in a form of a picture book in which images and text are equally important and interrelated (Figure 10.31).

Although visual responses such as drawing, painting, or photography, are not typically considered to be performing arts, the act of creating images is an embodied experience. In creating an image the reader can reveal his or her understanding of the text. Altering different media (crayons, markers, paint, chalk, photographs) have an impact on comprehension and interpretation as well (Video 10.10).

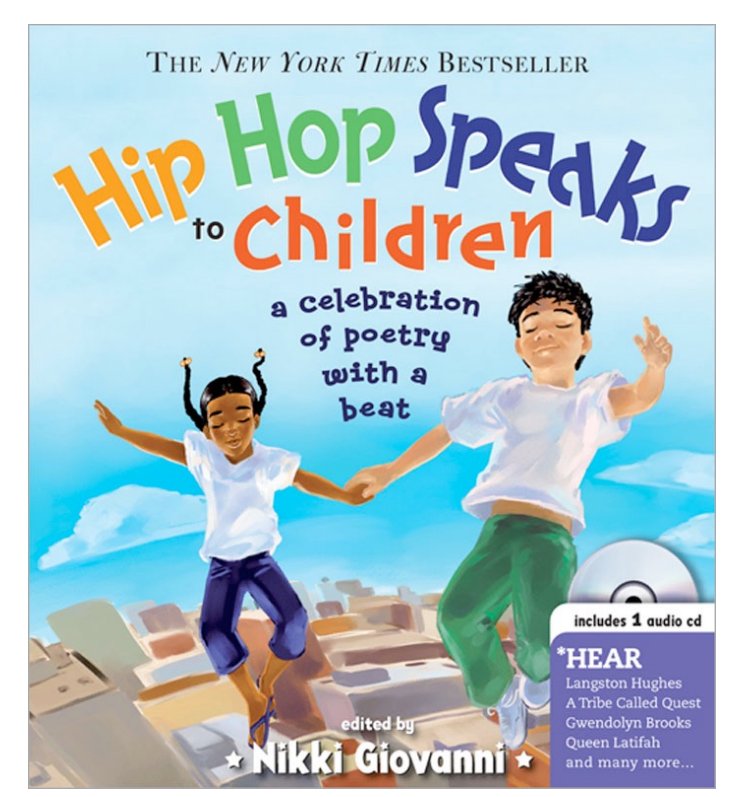

Figure 10.31

As Nikki Giovanni states in her introduction, Hip Hop is modern opera, with truthful tales surrounded by public commentary. This collection of poetry includes celebrated children's poets, musicians, and rappers telling stories. Hip Hop Speaks to Children: A Celebration of Poetry with a Beat selected by Nikki Giovanni and illustrated by Michele Noiset and Jeremy Tugeau, 2008, Naperville, IL: Sourcebooks. Cover art copyright 2008 by Michele Noiset and Jeremy Tugeau.

\section{BUILDING A POEM}

\section{WITH CSABA OSVATH}

\section{THE INSIDE, OUTSIDE, AND UPSIDE DOWNS $\mid$ From Poets and Pop-ups to Princesses OF CHLLDREN'S LITERATURE}




\section{Creating Poetry by Csaba Osvath}

In children's poetry, there are poets who construct visual or concrete poetry by creating visual compositions where the text and visual elements (e.g., pictures, typeface, colors, layout, balance) are inseparable. A famous example is Lewis Carroll's 'Mouse's Tale' in Alice's Adventures in Wonderland, where the text is shaped as a long, curving tail (Figure 10.32).

Another type of visual poetry is graphic poetry, where images are intentionally matched with a text to aid comprehension and interpretation. In the production of filmed, spoken-word poetry, many poets will augment their recitation with images and words to enhance the experience of engaging with their poems on the screen. As such, visual and concrete poems offer layers of interaction with the reader (Figure 10.33). By creating visual, graphic, or concrete poems the poet offers new approaches to communicate or to connect with the audience.

Poetry: A Slippery Slide. Of course, as a mature person, you might think that your beliefs about poetry are irrelevant in the context of poetry in an academic course in children's literature. Additionally, you might think that learning about poetry related to children's literature has little connection to your "adult" life and the problems related to adulthood. However, consider Lemony Snicket's introduction to a children's poetry portfolio, 'All Good Slides Are Slippery', in Poetry magazine where he wrote:

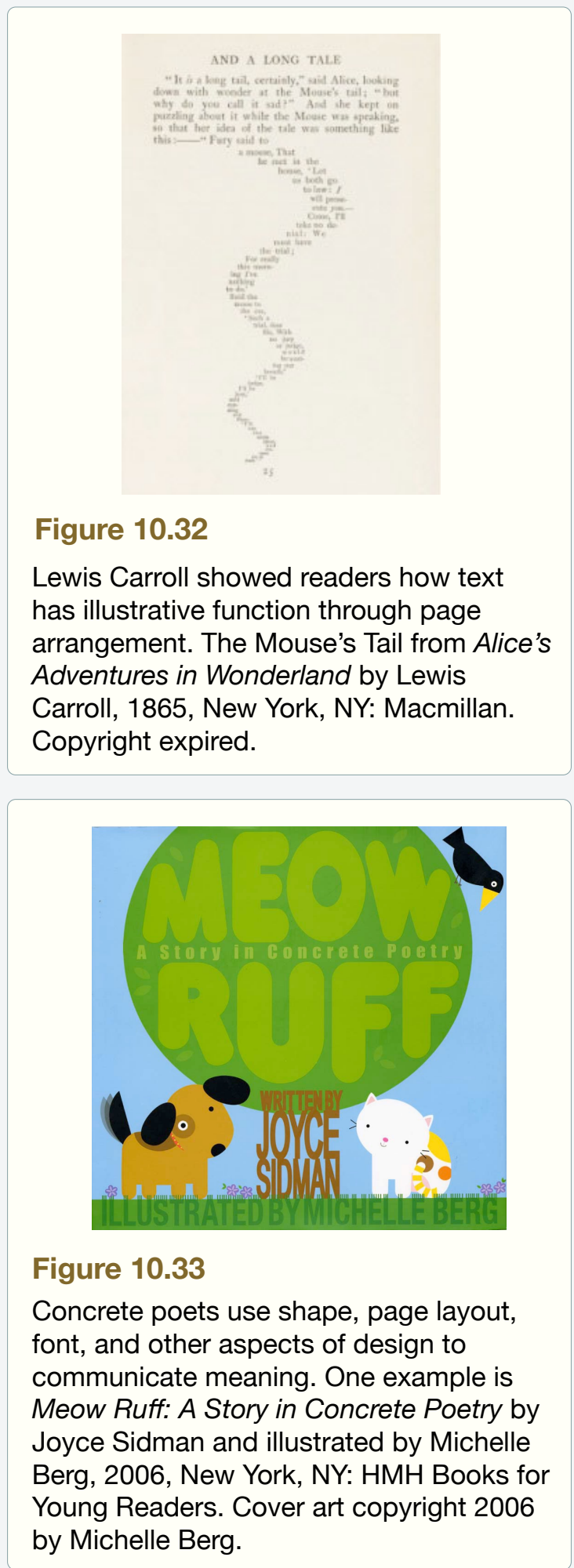

Figure 10.32 Adventures in Wonderland by Lewis Carroll, 1865, New York, NY: Macmillan. Copyright expired.

Figure 10.33 font, and other aspects of design to ane example is Meow Ruft: A Story in Concrete Poetry by Berg, 2006, New York, NY: HMH Books for by Michelle Berg.

The poems contained in this children's poetry portfolio are not made for children. Poetry is like a curvy slide in a playground - an odd object, available to the public - and, as I keep explaining to my local police force, everyone should be able to use it, not just those of a certain age (See more at http://www.poetryfoundation.org/poetrymagazine/article/246328). 
I personally agree with Snicket. Poetry is a kind of functional architecture or a transportation device that is asking us to inhabit it and to use it with the added possibility of joy, thrill, or even fear. Snicket does not mention the intellectual abilities of children when it comes to poetry. He never writes that these poems are too complex, or too difficult, or too challenging for a young audience. He suggests that understanding might not even be a necessary prerequisite for engaging with poetry. In fact, even if you don't understand what the author meant to say, the poem still communicates to you. The poem can still reach you and impact your life, incite and ignite feelings, reveal ideas, etc. Consider, the short poem from the portfolio by Eileen Myles, titled "Uppity" (http://www.poetryfoundation.org/poetrymagazine/poem/246366).

\title{
Uppity
}

\section{Roads around mountains}

\author{
cause we can't drive
}

through

That's Poetry

to Me.

(Eileen Myles, 2013)

What does the poet mean in this poem? Are the roads a metaphor for words? Or are the roads a metaphor for contemplation? Is there a point to explain this poem, or is the experience of reading the poem, simply, meaningful? Again, Snicket hits the mark when he writes about the essence of poetry in the context of a children's literature:

If you are a child, you might like these poems. Of course, you might not. Poems, like children, are individuals, and will not be liked by every single person who happens to come across them. So you may consider this portfolio a gathering of people in a room. It does not matter how old they are, or how old you are yourself. What matters is that there are a bunch of people standing around in a room, and you might want to look at them. 
Ars Poetica. All this leads to some important conclusions. Poetry is communal, regardless of the age or the "maturity" of its audience. Poetry does not function in isolation. Poetry thrives on interpersonal connections and on the use of voice and speech. Poetry thrives when it is "said out loud" and heard by "a bunch of peoples standing around." So the questions loop back around and pose questions that answer, "What do you believe about poetry?" "Do you need poetry in your life?" And most importantly, "What can poetry offer you?"

When I now ponder these questions, I recall the story of a young boy, Gregory Orr, who is now a college professor of English. Through a project organized by National Public Radio (NPR) he tells a poignant, but inspiring story about a tragic childhood accident in his life and the role of poetry. Orr goes as far as to elevate poetry and the writing of poems as tools for survival. Orr reveals that for him, poetry and the making of poems are a "way of surviving the emotional chaos, spiritual confusion, and traumatic events that come with being alive" (http://www.npr.org/templates/story/ story.php?storyId $=5221496$ ). The author shares how traumatic violence isolates us and makes us numb. For him, the act of writing and actively sharing poetry with others became the essential tool to process his painful experiences and translate them into words. And when we are able to translate experiences into words, we realize that we are no longer powerless. Instead, we can actively shape our memories and our pain into poems. And through the act of sharing, we realize that we are no longer alone. We are, indeed, part of humanity. 


\section{Exploring Poetry}

The work of the great poets often serve as our introduction to poetry, but irrelevant teaching practices may have taken many of us away. Take a look at poetry for children and young adults. Revisit the classics and modern adult poetry as well. But do so by creating embodied experiences, reading aloud, and playing with the words, shapes, and meaning of poetry. Bottom line: you will find new meaning.

Sharing great poetry with children is not only a catalyst of change, but it is a valuable and diverse tool that poets (even emergent or amateur ones) can master and utilize in order to express their feelings, ideas, thoughts, dreams. Poetry allows us to connect with others, which eliminates fear from the "other." The key or the foundation for this responsibility begins with our willingness to engage with and to learn about poetry that is written, created, spoken, and intended for children or youth. 